Portland State University

PDXScholar

6-9-1997

\title{
Teaching Peace Education in ESL/EFL Classes: An International Perspective
}

Cheryl Lynn Hill

Portland State University

Follow this and additional works at: https://pdxscholar.library.pdx.edu/open_access_etds

Part of the Bilingual, Multilingual, and Multicultural Education Commons Let us know how access to this document benefits you.

\section{Recommended Citation}

Hill, Cheryl Lynn, "Teaching Peace Education in ESL/EFL Classes: An International Perspective" (1997). Dissertations and Theses. Paper 5350.

https://doi.org/10.15760/etd.7223

This Thesis is brought to you for free and open access. It has been accepted for inclusion in Dissertations and Theses by an authorized administrator of PDXScholar. Please contact us if we can make this document more accessible: pdxscholar@pdx.edu. 
THESIS APPROVAL

The abstract and thesis of Cheryl Lynn Hill for the Master of Arts in Teaching English to Speakers of Other Languages were presented June 9, 1997, and accepted by the thesis committee and the department.

COMMITTEE APPROVALS:

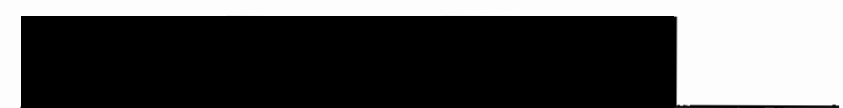

Kimberley Brown, Chair

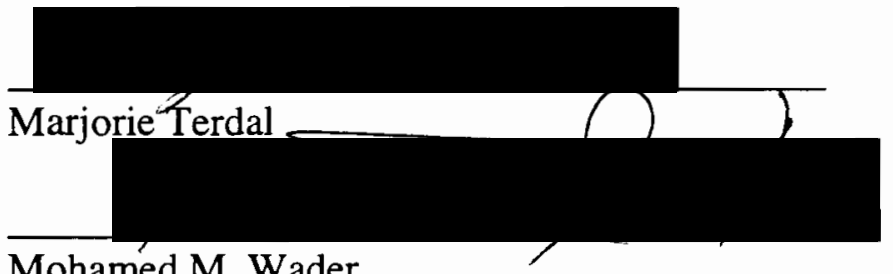

Mohamed M. Wader

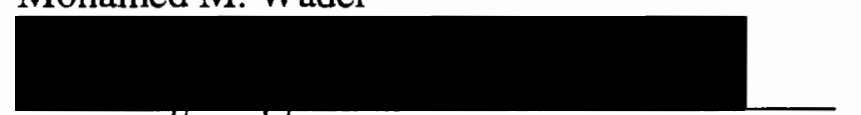

Dilafruz $R$. Williams

Representative of the Office of Graduate Studies

DEPARTMENT APPROVAL:

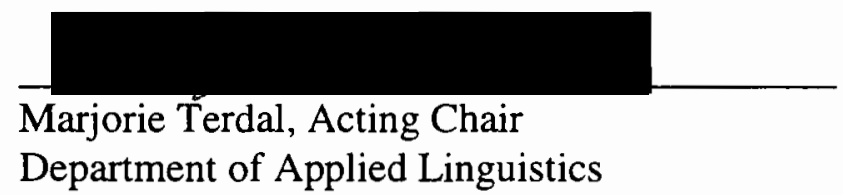

$* * * * * * * * * * * * * * * * * * * * * * * * * * * * * * * * * * * * * * * * * * * * * * * * * * * * * * * * * * * * * * * * * * * * *$

ACCEPTED FOR PORTLAND STATE UNIVERSITY BY THE LIBRARY

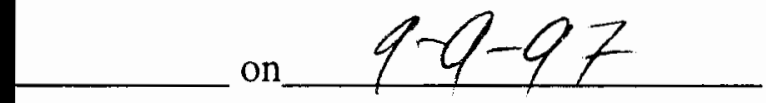




\begin{abstract}
An abstract of the thesis of Cheryl Lynn Hill for a Master of Arts in Teaching English to Speakers of Other Languages presented on June 9, 1997.
\end{abstract}

Title: Teaching Peace Education in ESL/EFL Classes: An International Perspective

This study offers an exploration of peace education ESL/EFL classes, from the perspective of the teacher and the students. Using questionnaires designed by the researcher, qualitative and quantitative survey data were collected from a convenience sample of thirteen ESL/EFL teachers and seventy ESL/EFL students. The teacher survey focuses on the following questions: 1) How do ESL/EFL teachers define peace education; 2) Why have some ESL/EFL teachers decided to teach peace education in their classes; and 3) How do ESL/EFL teachers incorporate peace education into their classes. The student survey carried out in three EFL classes in Israel, Italy, and Japan and one ESL class in the United States addresses the following questions: 1) Do any patterns emerge when examining the group of student subjects who show the greatest interest in peace issues; 2) Do any patterns emerge when examining the group of student subjects who show the least interest in peace issues; 3 ) Which materials do students find the most interesting and the most useful for improving their English; 4) 
Which activities do students like the most and find the most useful for improving their English.

Results from the teacher survey indicate that variation exists among teachers' definitions of peace education as well as the way in which teachers incorporate peace education into the ESL/EFL class. With regard to a rationale for teaching peace education, the category of response mentioned most frequently was "responsibility of the ESL/EFL teacher".

Student survey results seem to indicate that most subjects in the four participating classes were interested in and comfortable with peace issues. There appeared to be a connection between time spent in another country and interest in peace issues. Materials used in the four classes varied, and therefore no comparisons could be made. Among the activities assessed, group discussions scored highest in three classes as the activity that subjects liked the most. In all four classes, group discussions scored highest as the activity that helped subjects to improve their English the most. 
TEACHING PEACE EDUCATION IN ESL/EFL CLASSES:

AN INTERNATIONAL PERSPECTIVE

by

CHERYL LYNN HILL

A thesis submitted in partial fulfillment of the

requirements for the degree of

\author{
MASTER OF ARTS \\ in \\ TEACHING ENGLISH TO SPEAKERS OF OTHER LANGUAGES
}

Portland State University

1997 


\section{ACKNOWLEDGEMENTS}

To the participants of the Teacher and Student Surveys I am very thankful. Thank you for openly sharing your thoughts and giving freely of your time. One of the greatest rewards of having carried out this study was coming into contact with so many caring individuals who are each contributing in a unique way toward the creation of a more peaceful planet.

I am deeply grateful for the constant support and invaluable suggestions of my thesis advisor and friend, Kim Brown. Thank you for the many times that you encouraged me when yet another plan had fallen through. It is difficult to imagine having gone through the process without you! To my committee member Marge Terdal I owe many thanks for the time spent re-explaining issues of research design and methodology. Thanks for your patience. I owe many thanks to Mohamed Wader, a true peace educator, for offering to be a part of my thesis committee. From the Peace Seminar you taught and the many conversations with you I have learned what it means to not only teach peace, but to live peace. I owe many thanks also to Dilafruz Williams for agreeing after e-mailing back and forth to serve as the Graduate Office Representative of my thesis committee. Thank you for your valuable time.

Thanks to everyone in the Linguistics department, especially my former coworkers Susan, Annette, Talisman, and Karin. It has been a wonderful four years 
because of all of you!!

Many thanks to Rudolf Lublinsky for help with analyzing the EFL I Survey data. Thanks to Cliff Barnett for assistance during the final stages of writing. To Mikey McKillip, the computer wizard, thanks for help with the final touches on Figure 2.1. I am very grateful to Thomas Luttmann for coming to my rescue many times when I hit road blocks. Not only have you supported me with your computer expertise but also you have been there as my friend.

To all of my family members and friends THANK YOU!! I love you all!! I could not have done it without your constant support and love. 


\section{TABLE OF CONTENTS}

PAGE

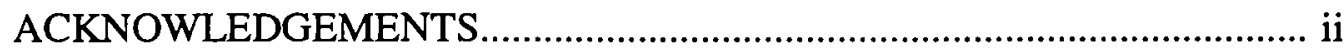

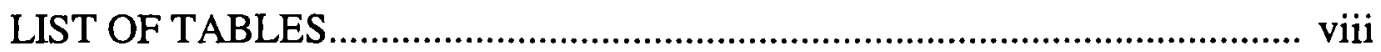

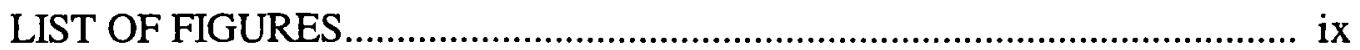

\section{CHAPTER}

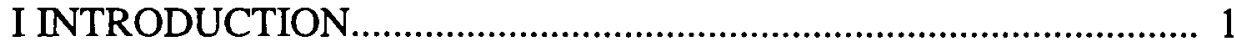

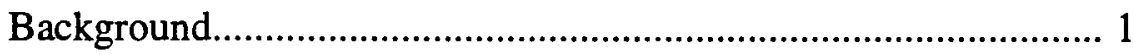

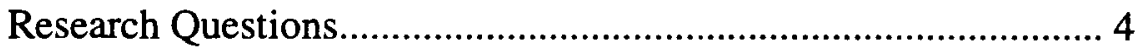

Glossary of Terms

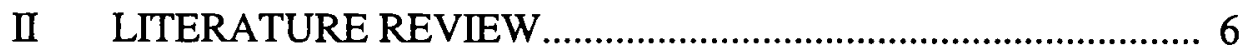

Defining Peace Education............................................................. 7

Defining Peace

Peace Research/Peace Education

Objectives of Peace Education

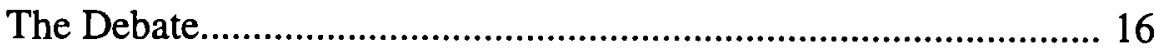

Rationale for Teaching Peace Education in

ESL/EFL Classes..................................................................... 21

Language in Context

TESOL's Link with the United Nations 
The Expanding Role of the ESL/EFL Teacher

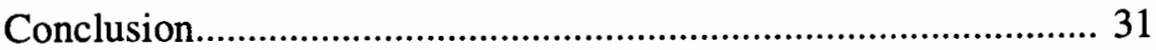

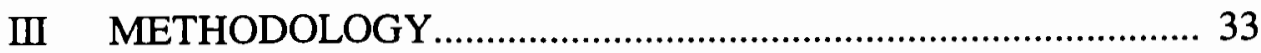

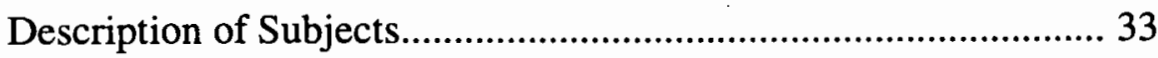

Teacher Survey Participants

ESL Teacher Participants

EFL Teacher Participants

Student Survey Participants

Instruments.......................................................................... 43

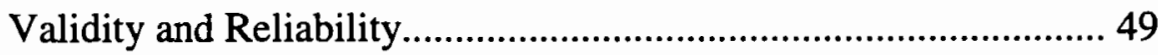

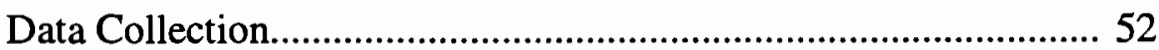

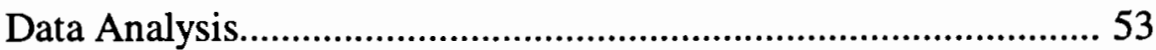

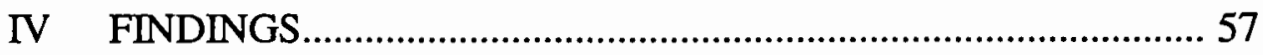

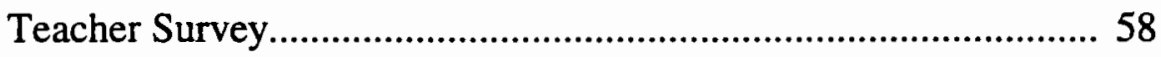

Defining Peace Education

Rationale for Teaching Peace Education

How Peace Education is Taught in ESL/EFL Classes

How Students Have Responded---In the Teachers' Words

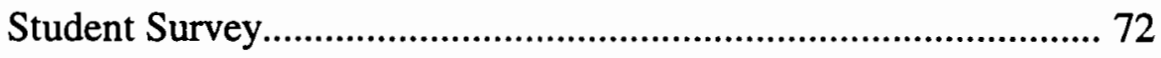

Background 
Response Rate

Results of Survey Items Measuring Interest and

Comfort

Interest and Comfort of Subjects in Israel and Italy

Interest and Comfort of Subjects in Japan and the United States

Assessment of Materials

Assessment of Activities

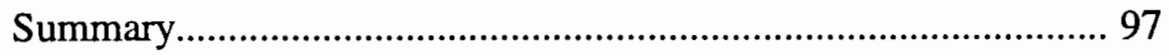

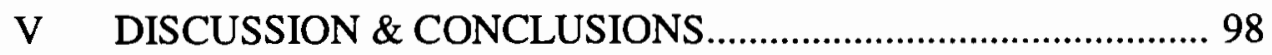

Discussion of the Findings............................................................. 98

Teacher Survey

Student Survey

Limitations of the Study............................................................ 107

Suggestions for Further Research................................................ 108

Implications for the Field of TESOL............................................. 110

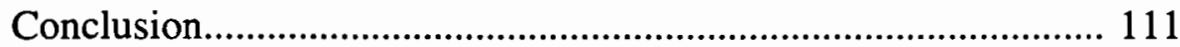

REFERENCES

\section{APPENDICIES}

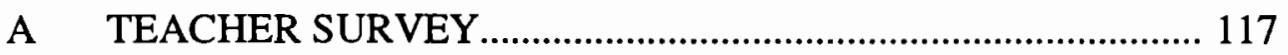

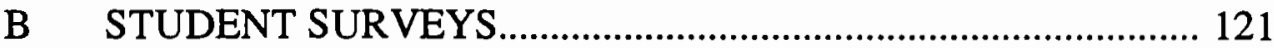

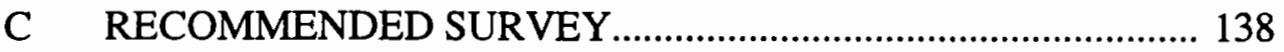


2.1 Framework for Peace Education......................................................... 15

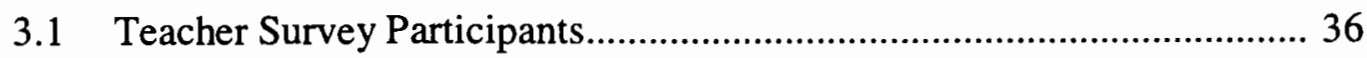

3.2 Student Survey Participants................................................................. 41

3.3 Correspondence of Survey Items with Research Questions..................... 56

4.1 Teachers' Definitions of Peace Education................................................6 60

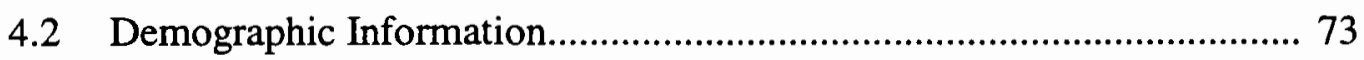

4.3 Profile of Participating ESL/EFL Classes............................................. 75

4.4 Students' Assessment of Materials........................................................ 93

4.5 Students' Assessment of Activities......................................................... 95 


\section{LIST OF FIGURES}

FIGURE

PAGE

2.1 Peace Education Objectives........................................................ 14

4.1 Interest \& Comfort of Subjects in Israel.............................................. 81

4.2 Interest \& Comfort of Subjects in Italy .............................................. 81

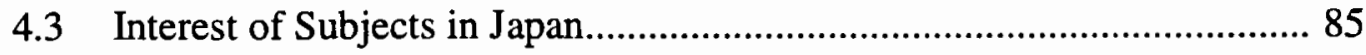

4.4 Interest of Subjects in the United States................................................ 85

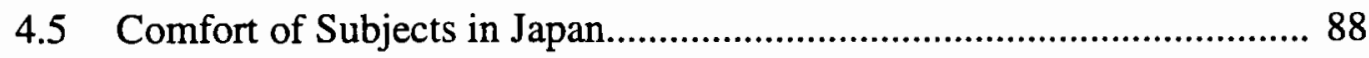

4.6 Comfort of Subjects in the United States.............................................. 88 


\section{CHAPTER I}

\section{INTRODUCTION}

In the fall of 1991, the researcher was first introduced to "peace education" at the Japan Association of Language Teachers' (JALT) annual conference in Kobe, Japan. At the invitation of JALT's Global Issues in Language Education National Special Interest Group, Valentina Mitina of the former Soviet Union gave a presentation on teaching peace education in English as a Foreign Language (EFL) classes. For twenty years Mitina taught peace education in her EFL classes in Moscow. It was this conference presentation which inspired the researcher to carry out the following study on teaching peace education in English as a Second and Foreign Language classes.

Within the field of Teaching English to Speakers of Other Languages (TESOL), interest in incorporating peace education into English as a Second Language (ESL) and English as a Foreign Language (EFL) classes has increased since the 1980s. Evidence of this growing interest can be seen in the number of journal articles that have been written on teaching peace education, conference presentations given, as well as entire language teaching conferences that have been organized around the theme of teaching peace education. Support for this new development within the field of 
TESOL has been met with varying responses. Some educators have enthusiastically embraced peace education while others claim that peace education is a form of indoctrination. To the knowledge of the researcher, no studies have been carried out on ESL/EFL classes with a peace education focus; therefore, much of the debate over the appropriateness of peace education for the ESL/EFL class seems to be based on each teacher's personal opinion. Many of the ESL/EFL educators who have leveled criticism against peace education appear to have no theory base in peace education. According to Reardon (1988), peace education uses a systems approach, an approach which involves examining phenomena in context from the perspective of many disciplines. Galtung (1985) asserts that a peace researcher should aim to become ever more trans-disciplinary and trans-national; "Essentially it means that the original discipline and nationality of the peace researcher [or peace educator] would tend to wash out as the researcher [or educator] matures" (p. 144). The approaches to peace education and peace research described by Reardon and Galtung call for a move away from dualistic, either-or thinking toward holistic, global thinking. One of the aims of peace education is to challenge indoctrination of all kinds. Definitions of peace education will be addressed further in Chapter 2. The researcher's definition of peace education which changed over the course of this study is discussed in Chapter 5 (p. 111)

To the ESL/EFL class, each student and the teacher brings a unique system of beliefs, skills, and background knowledge, creating a complex community. This 
environment seems not only appropriate, but an especially suited place for the teaching of peace education. As mentioned above, peace education is based on a systems approach; it is trans-disciplinary as well as trans-national. Peace education seeks not to impose one system on another, but rather to bring together systems in order to gain a more holistic, global perspective.

Despite the debate over the appropriateness of peace education for the ESL/EFL class, there is evidence, as mentioned above, that interest in peace education is growing. As more and more teachers begin to incorporate peace education into their ESL/EFL classes, it is important that a greater understanding of this newly developing field be achieved. Ashworth (1990) asserts, "We must develop clear definitions of peace and peace education along with a definitive statement of the aims of peace education" (p. 4). This study offers an exploration of peace education ESL/EFL classes, from the perspective of the teacher and the students. Using questionnaires designed by the researcher, qualitative and quantitative survey data were collected from a convenience sample of thirteen teachers and seventy students of ESL/EFL classes which taught peace issues as the central theme or a sub-topic. The teacher survey was carried out with seven ESL and six EFL teachers. Student survey data were collected in three EFL classes (in Israel, Italy, and Japan) and one ESL class in the United States. In the three EFL classes, peace issues were the central theme. The ESL class addressed global issues as the central theme and peace issues as a subtopic. 
The following research questions were the focus of this study. Research questions 1,2 , and 3 are addressed by the teacher survey. Student survey data collected address research questions $4,5,6$, and 7 .

(1) How do ESL/EFL teachers define peace education?

(2) Why have some ESL/EFL teachers decided to teach peace education in their classes?

(3) How do ESL/EFL teachers incorporate peace education into their classes?

(4) Do any patterns emerge when examining the group of student subjects who show the greatest interest in peace issues?

(5) Do any patterns emerge when examining the group of student subjects who show the least interest in peace issues?

(6) Which materials do students find the most interesting and the most useful for improving their English?

(7) Which activities do students like the most and find the most useful for improving their English?

\section{Glossary of Terms}

Development Education "Education which has as its critical concern world poverty and underdevelopment, focused primarily on the economic relations between the industrial nations and the developing ones" (Reardon, 1988, p. 6). 
Environmental Education education "aimed at producing a citizenry that is knowledgeable concerning the environment and its problems, aware of how to help solve those problems, and motivated to work toward their solution" (Stapp et al in Wilke, 1993).

Human Rights Education "Education centered on international human rights standards and their constant and widespread violation" (Reardon, 1988, p. 6).

Peace Research research which explicitly values peace, is trans-disciplinary and trans-national. (Galtung, 1985) 


\section{CHAPTER II}

\section{LITERATURE REVIEW}

Since the 1980s more and more teachers of English to speakers of other languages have begun teaching peace education in their ESL/EFL classes. This is evident in the number of articles and books that have been written on this topic (Ashworth, 1990; Birch, 1992; Fox, 1990; Ghaith \& Shaaban, 1994; Larson, 1992; and Wenden, 1990). In addition, many presentations have been given on peace education at professional language teaching conferences such as the Japan Association of Language Teachers (JALT) and Teachers of English to Speakers of Other Languages (TESOL). Peace education was the theme of the 1995 TESOL Institute held in Vermont. However, despite this increasing interest in peace education, there still remains much debate over its appropriateness for the ESL/EFL class. Some teachers claim that peace education is a form of political indoctrination. Other concerns are that the students may be uninterested in the content or uncomfortable dealing with controversial issues. This chapter discusses definitions of peace education, addresses issues in the debate over teaching peace education, and finally looks at a rationale for teaching peace education in ESL/EFL classes. 


\section{Defining Peace Education}

Ashworth (1990), ESL teacher, teacher trainer and Professor Emerita at the University of British Columbia, points out that, "We must develop clear definitions of peace and peace education along with a definitive statement of the aims of peace education" (p. 4). It became evident to the researcher, after reviewing the literature and attending conference presentations on peace education, that ESL/EFL teachers' definitions of peace education vary greatly. For those ESL/EFL educators already involved with teaching peace education, it seems that the link between ESL/EFL teaching and the teaching of peace education is quite clear. However, others would argue that little or no connection exists between the two fields.

\section{Defining Peace}

Defining peace education starts with the definition of peace; how peace is perceived has an influence on the how and what of teaching peace education. In all countries a concept of peace exists, with definitions varying from one language to another. In western countries, the over-use and mis-use of the word "peace" in the media and advertising have contributed to the difficulties of defining peace education. Although peace is commonly thought of as being a state, peace researchers and educators claim that peace is a process. Definitions of peace have broadened with the work of peace researchers such as Johan Galtung. 
The widespread notion of peace as the 'absence of war' changed in the 1960s when leading peace researcher Galtung (1985) coined the terms "negative peace" and "positive peace", which are now accepted by most peace researchers and educators. This distinction "expanded the field of study from prevention and control of war to the study of peaceful relations" (Galtung, 1985, p. 145). While negative peace is associated with the prevention and control of war, positive peace is related to such concepts as "harmony," "cooperation," and "integration." Reardon (1988) argues that peace education should aim to teach positive peace, introducing the skills, concepts, and values essential to the building of a more peaceful society.

\section{Peace Research/ Peace Education}

Just as definitions of peace are varied, so are definitions of peace education. In interviews with 50 peace educators from 22 countries, Bjerstedt (1994), former executive secretary of the Peace Education Commission of the International Peace Research Association, found that there was some disagreement on terminology within the field. With peace education being a new field, definitions are still changing. Bjerstedt's question "What do you think of first when you hear the words 'peace education" " elicited a variety of responses. While most interviewees had no objections to the term "peace education", some had negative or hesitant responses, indicating that it was vague and evoked negative stereotypes (Bjerstedt, p. 4). Those peace educators uncomfortable with the term 'peace education' mentioned that they 
use alternative terms such as 'peace learning', 'nuclear age education', 'disarmament education', or 'collective learning about peace'.

In his overview of the global peace education movement, Okamoto (1993) states that peace is defined in various ways; as a result, peace education has many definitions.

It is natural, therefore, that peace education is conducted under such diverse labels as follows:

Education for International Understanding

Disarmament Education

Development Education

Human Rights Education

World Order Education

Education for Peace and Security

Global Education

International Education

Education for Liberation

Ecology Education

Justice Education

Environmental Education

Education for the Oppressed

A-bomb Education

Anti-Nuclear Education

Etc. (p. 18)

How are these different labels under which peace education is taught

connected? A brief historical overview of the events leading up to the genesis of the field of peace education will help to shed some light on this question. The following overview draws on the events outlined by Galtung (1985) and Reardon (1988), two leading peace researchers, educators, and activists.

In 1959, the International Peace Research Institute (PRIO) in Oslo was 
founded, with five researchers working on five programs. Galtung (1985) explains, “...this was the first institute after the Second World War openly professing a dedication to the study of 'peace' in its very name" (p.141). Later in 1964, with important support from the United Nations Educational Scientific Cultural Organization (UNESCO), the International Peace Research Association (IPRA) was formed. Growth in the field of peace research was evident at the tenth international conference of IPRA in 1986, which was attended by 300 researchers from as many as thirty countries across the world.

A network of educators from the International Peace Research Association formed the Peace Education Commission (PEC) in 1972. Co-founder of PEC (together with Galtung and others), Reardon (1988), explains that the activities of the PEC included carrying out research, publishing articles in international journals such as Bulletin of Peace Proposals, and meeting during conferences sponsored by UNESCO and the World Order Models Project (WOMP).

In her discussion on the development of the field of peace education, Reardon (1988) mentions three main influences: world order inquiry, transnational cooperation, and national networking. In 1963, the Institute for World Order, the forerunner of WOMP, was established to conduct peace research and education, beginning with a focus on secondary education. Formerly a social studies teacher in secondary schools, Reardon left her teaching position to become the director of the Institute for World Order. The aim of the Institute for World Order, Reardon explains, was "to introduce 
to the American public alternatives to war, in the form of possibilities for new international institutions" $(1988$, p. 1). Over its first five years, the Institute for World Order developed an approach that "was based on the assertion that study of the issues must take place within a context that [is] global, interdisciplinary, based on a systems approach to the study of peacekeeping and dispute-settlement procedures, futuristic, and value-based" (Reardon, 1988, p. 1).

In 1970, researchers from the Institute for World Order formed WOMP, a group of researchers from around the world who meet on a regular basis to work together on common research efforts. Influenced by WOMP, the field of world order studies adopted a value orientation, which became one of the characteristics to distinguish this field and the field of peace education from international relations and international education.

World Order Studies value-oriented futuristic transnational
International Relations/ Education presumed value-free deals with past and present international

In addition to the influence of the World Order Models Project and the Peace Education Commission, Reardon (1988) discusses the contributions of national networking in the United States. In the late 1960s, IPRA's North American affiliate was established, the Consortium on Peace Research Education and Development (COPRED). In the late 1970s, the Peace Education Network (PEN) was formed. 
Through PEN, elementary and secondary school teachers in the United States with an interest in peace education could meet and share ideas. It was primarily the efforts of PEN which brought the concept of nonviolent conflict resolution into American peace education.

The efforts made by concerned researchers and educators from across the world have led to the development of the field of peace education. A characteristic of peace education includes a value orientation, valuing peace and opposing violence. Peace education is also futuristic and transnational. If the objectives of peace education are "...to promote the development of an authentic planetary consciousness that will enable us to function as global citizens and to transform the present human condition by changing the social structures and the patterns of thought that have created it" (Reardon, 1988, p. x), then it is necessary to have a genuine concern for peace issues, to be able to imagine a more peaceful world, and to look beyond national borders and view all living beings as part of one family.

EFL educator and editor of the Global Issues in Language Education Network of the Japan Association of Language Teachers, Cates (1992), points out that when experts in the field mention the term "peace education", most are referring to Reardon's (1988) “comprehensive peace education" (Cates, p. 3). Between global education and comprehensive peace education there is much overlap, with the focus differing slightly. Because of this many educators use the terms "peace education" and "global education" interchangeably (Cates, p. 3). Peace education includes three 
curricular approaches: environmental education, development education, and human rights education. Reardon (1988) explains, "Whether a curriculum in any of these areas can be classified as peace education depends on its value content and its treatment of the core problem addressed by peace education: violence" (p. 31).

\section{Objectives of Peace Education}

In Figure 2.1, Hicks (1988) summarizes the objectives of peace education with regard to knowledge, skills and attitudes. According to Hicks (1988), the knowledge taught in peace education classes deals with issues of conflict, peace, war, nuclear issues, justice, power, gender, race, ecology, and futures. This is consistent with Reardon's definition of "comprehensive peace education", which involves the study of development, human rights and environmental issues. The skills taught include critical thinking, cooperation, empathy, assertiveness and conflict resolution. Lastly, the attitudes that are nurtured are self-respect, respect for others, ecological concern, open-mindedness, vision, and commitment to justice. Objectives within the context of ESL/EFL classes may vary somewhat depending on the individual teacher's definition of peace education.

For the context of ESL/EFL classes, Ghaith and Shaaban (1994) developed a framework for incorporating peace education. This framework draws on the work of Cates (1992), Fine (1990), Fox (1992), Jacobs (1990), Larson (1990), and Ashworth (1991), among others. The dimensions within the framework (themes, skills, methods, 
FIGURE 2.1

PEACE EDUCATION

OBJECTIVES

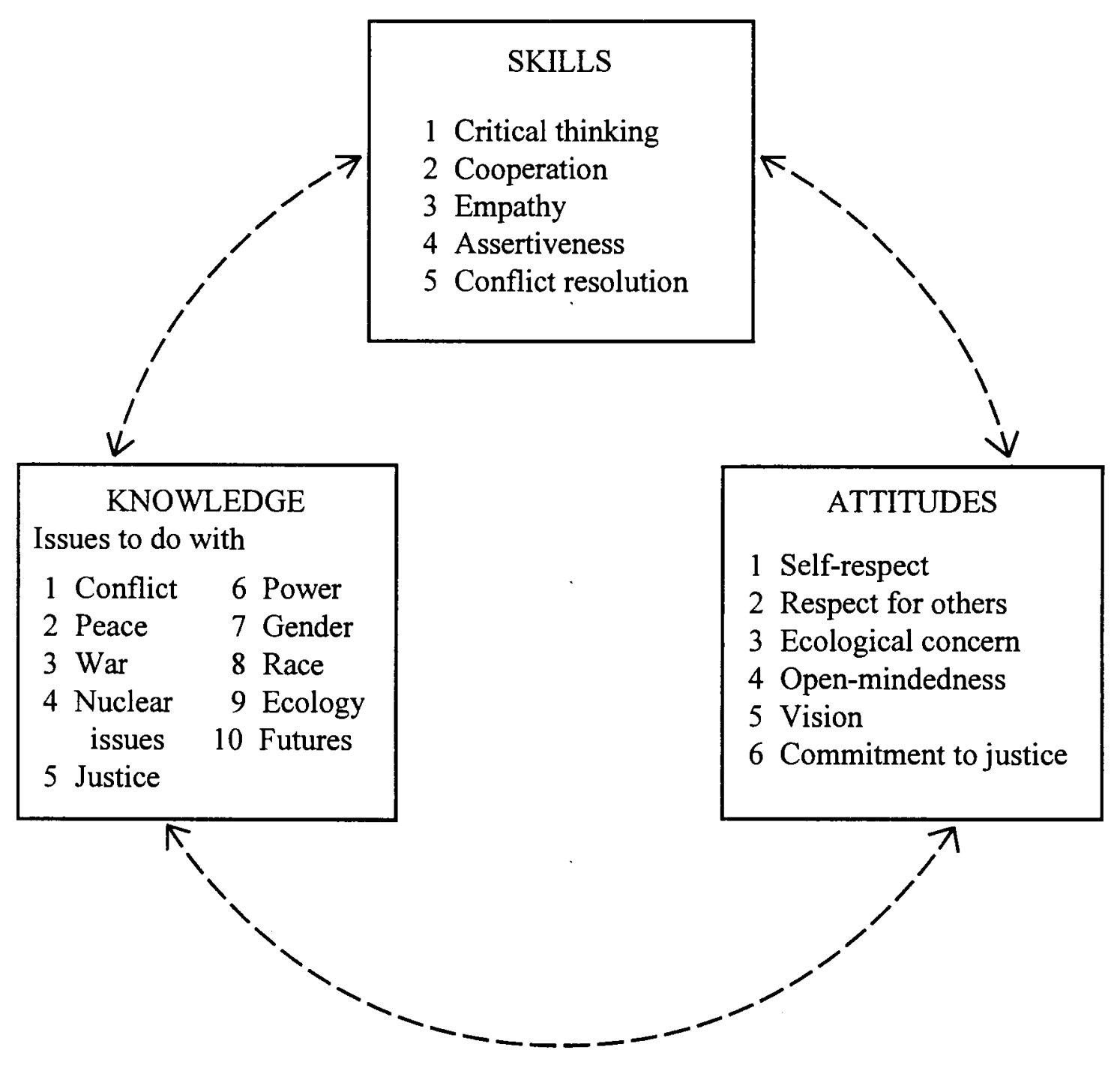

(Hicks, 1988, p. 13) 
materials) occur simultaneously. Ghaith and Shaaban (1994) explain that "the theme of communication," for example, "interrelates with the skill of negotiation and the instructional methods of teaching culture and literature" (p. 56).

TABLE 2.1 FRAMEWORK FOR PEACE EDUCATION

\begin{tabular}{|l|l|l|l|}
\hline THEMES & SKILLS & METHODS & MATERIALS \\
\hline Communication & Negotiation & $\begin{array}{l}\text { Cooperative } \\
\text { learning }\end{array}$ & Media \\
\hline Environment & Managing anger & $\begin{array}{l}\text { Methods of } \\
\text { teaching culture }\end{array}$ & Literature \\
\hline $\begin{array}{l}\text { Constructive } \\
\text { conflict }\end{array}$ & Mediating conflict & $\begin{array}{l}\text { Literature-based } \\
\text { instruction }\end{array}$ & Games/ Puzzles \\
\hline $\begin{array}{l}\text { Peaceful } \\
\text { coexistence }\end{array}$ & $\begin{array}{l}\text { Tolerance of } \\
\text { ambiguity } \\
\text { Critical thinking }\end{array}$ & $\begin{array}{l}\text { Humanistic } \\
\text { methods }\end{array}$ & $\begin{array}{l}\text { Amnesty Inter- } \\
\text { national Report/ } \\
\text { Non-governmental } \\
\text { organizations' } \\
\text { reports }\end{array}$ \\
\hline
\end{tabular}

Note: Ghaith and Shaaban included a fifth category, "assessment", which has been omitted, due to the fact that this study does not address issues of assessment.

(Ghaith \& Shaaban, 1994, p. 57)

Ghaith and Shaaban (1994) add, "[E]ducators adopting the framework might work for achieving the main goals of creating awareness within their students about variations in communication, environmental hazards, and all forms of violence" (p. $60)$.

Birch (1992) asserts that teaching peace education can be carried out by not 
only teaching peace concepts explicitly, but also by creating an atmosphere of trust, cooperation and respect in the classroom. Birch cites four examples of teachers who did not have as one of their goals to teach peace education; however, for each of them, creating a safe, comfortable classroom atmosphere was important. Through their behavior, these educators were teaching concepts of peace, such as respect, trust, and social justice.

In peace education classes the skills of critical thinking, cooperation, empathy, assertiveness and conflict resolution are developed as students read, write and speak about human rights, development, and environmental issues. Teachers use primarily authentic materials (newspaper articles, literature, songs) and a variety of activities (debates, group discussion, role plays) to investigate world problems (with a focus on all forms of violence) from many perspectives and propose solutions to those problems. An essential dimension to peace education classes is the action component. This aspect of peace education and the value orientation are what seem to evoke the most criticism.

The Debate

In her article on teaching conflict resolution in ESL classes, Fine (1990) mentions that some teachers have voiced concerns about integrating peace education and conflict resolution into the ESL class. These teachers mentioned the issues of 
propaganda and bias and wondered if the topic might be too political. In addition, teachers mentioned a concern about how to handle conflicts which might arise.

Mitina (1990) points out that in Russia "foreign language teaching and peace education are seen as dialectically connected processes...foreign language knowledge increases the capacity for positive communication, for constructive conflict resolution and for overcoming negative stereotypes" (p. 23).

Reardon (1988) discusses the controversies around the value-base of the field of peace education:

The values and action dimensions of peace education have been a significant source of controversy.... Accusations of bias have been leveled at peace education and peace studies from many sides, by academic as well as by professional unions and school administrations. Unfortunately most of these accusations...stem from the prevailing pattern of dualistic, either-or thinking that permeates [American] culture and...politics, reflecting the fallacious notion that to be objective means to be value-free. (p. 22)

Using the analogy of the field of medicine, which values health and opposes illness and disease, Galtung (1985) points out the importance of the value-base of peace research and peace education.

As part of a series of interviews with 50 peace educators from 22 countries, Bjerstedt (1995) asks participants, "In many countries, questions related to disarmament and peace are highly controversial. Would you anticipate any difficulties, for example with parents or other members of the community, when introducing peace education in the schools?" Bjerstedt writes that “...a very large majority report controversies around peace education... This is especially true for 
respondents from Europe and North America" (1995, p. 6). The "culture of militarism" (1995, p. 6) and "stereotyped thinking of much debate in the mass media" (1995, p. 7) were examples given as obstacles to the teaching of peace education.

With regard to the concern of some ESL/EFL teachers of becoming involved in education which is political, Eggington (1992/1993) points out that "the language we teach carries so much sociocultural and political weight that it is probably impossible to escape the sociopolitical nature of our field" (p. 4). Eggington (1992/1993) affirms that there are two opposing tensions within TESOL: English as a language of social empowerment and English as a language of cultural imperialism. On the one hand, English can become a resource which provides learners with access to educational, political and economic opportunities. On the other hand, teaching English can also lead to the spread of western values. Eggington (1992/1993) concludes, "The challenge for ESL teachers is to manage the tension between the empowering and imperialistic natures of English" (p. 4).

In response to Eggington (1992/1993), ESL/EFL teacher, Jones (1993) exclaims:

For years I battled teachers in the US who used their ESL classes to proclaim their own political platforms. When I left the United States in 1991 , the "content-based approach" was in full swing at the university ESL institute where I taught. Culture teaching was being given preference to language teaching, but it was culture teaching based on individual prejudices and biases and very obviously and blatantly chauvinistic. (p. 19)

Jones (1993) cites examples of "culture teaching", which she claims is fine "in its 
place": addressing issues such as AIDS, crime, drugs and carrying out activities such as watching a video on Martin Luther King or listening to songs by Tracy Chapman (p. 19).

Responding to Jones (1993), Eggington (1993) agrees that teachers should be cautioned against taking a "'nutritionalists' approach to both language and languagethrough-content teaching where we, as the all-knowing and all-powerful masters of the classroom, feed bits of our 'correct' sociopolitical culture and our 'superior' language to our undernourished students" (p. 19). However, Eggington (1993) disagrees with Jones (1993) that it is possible to avoid the "sociopolitical implications of language teaching" (p. 19). He adds, "No matter what we do, how we do it, or where we do it, we are still buying into systems that empower or disempower, or that impose one culture onto another" (Eggington: 1993, p. 19).

Jacobs (1993/1994), an instructor who incorporates the teaching of social issues into his content-based ESL classes in Singapore, also addresses Jones (1993). As his rationale for using the content-based approach, Jacobs (1993/1994, p. 15) refers to the work of Brinton, Snow, and Wesche (1989), "I believe that content-based instruction aids language learning because contextualized use of the target language is more conducive to learning than is a focus on decontextualized language usage". With a focus on content, students can improve their level of proficiency faster than when the focus is on form. Language across the curricula, language for specific purposes, and thinking skills instruction are movements in education which "recognize 
that our minds store information in connected chunks, not isolated bits. Additionally, content-based instruction, particularly the use of socially oriented themes, represents an effort to link school with the world in which students live. This is a return to a humanistic view of educationists' role as professionals who seek to educate students to be participative, well-rounded citizens, not specialized cogs" (Jacobs, 1993/1994, p. $15)$.

Former editor of Sociopolitical Concerns of TESOL Matters, Ricento (1993/1994), comments on the debate between Eggington (1992) and Jones (1993).

Unfortunately, culture reflected in mass media, and especially in entertainment, is hardly neutral, and often reinforces stereotypes or deals with highly emotional and controversial subject matter... It would be difficult to find an ESLEFL student with a cultural tabula rasa. If this is true, how can teachers afford to ignore culture, since silence on such important matters may only serve to reinforce erroneous, or certainly incomplete, or uninformed, beliefs and stereotypes. (p. 15)

Ricento (1993/1994) points out, as does Eggington (1992), that ESLEFL teachers need to be aware of the implications that their curricular and methodological choices have on their students. "The teaching of culture, including the content of that teaching, is never an either/or proposition, but one of degree and kind" (Ricento, 1993/1994, p. 15).

Galtung (1985) emphasizes the importance of a theory base for peace researchers: "Much more dangerous than [peace researchers being interested in education and action] would be those who engage in education and action without any research basis and for that reason have a tendency to repeat their own cherished 
beliefs, whether those of the establishment or the anti-establishment, trying to shape the world according to their dogmas" (p. 148). Peace educators, too, must be aware of the importance of having a theory base in order that the selection of methods, themes, materials, and activities are not motivated simply by personally "cherished beliefs," but rather grounded in the theory of peace education and peace research.

\section{Rationale for Teaching Peace Education in ESL/EFL Classes}

At the same time that interest in peace education among ESL/EFL teachers is growing, there seems to be an increased interest in teaching methods and objectives which are compatible with the goals of peace education, as is evident from Brown's (1991) comments on the 25th anniversary of TESOL. Brown (1991) identified four central themes that seemed to emerge in ESOL teaching at the beginning of the 1990s: 1) empowering students; 2) a focus on sociopolitical issues; 3 ) making curricula more content-centered and task-based, emphasizing the teaching of global issues; and, 4) a shift toward cooperative, learner-centered methods, with a focus on learner strategies (p. 245). For some ESL/EFL teachers, the use of global or peace issues in the language class may mean nothing more than "just another theme" for a content-based class. In ensuing sections of this chapter, examples will be given from teachers who incorporate peace issues into the ESL/EFL class. First, a discussion is given on the content-based approach, an approach to second language teaching which has brought 
many ESOL teachers into contact with peace issues.

\section{Language in Context}

In the last 20 years, the content-based approach has become more widely used in Canada, the United States, and the United Kingdom, due to awareness of the advantages of studying language in context (Oxford, 1993). According to Brinton, Snow and Wesche (1989), content-based instruction is "the integration of content learning with language aims. More specifically, it refers to the concurrent study of language and subject matter, with the form and sequence of language presentation dictated by content material" (p. vii). The rationale for the use of the content-based approach in many ESL classes today stems from the claim that "a second language is learned most effectively when used as the medium to convey informational content of interest and relevance to the learner" (Brinton, Snow \& Wesche, 1989, p. vii).

Brinton, Snow, and Wesche (1989) discuss three models of content-based second-language instruction: theme-based, sheltered, and adjunct. Most ESL/EFL classes which incorporate peace education fall under the theme-based model. Within the theme-based model, the language teacher is also the content teacher, which gives this model the potential to "tie together the different skill areas via the contextual theme" (p. 28). Additionally, the theme-based model can be employed in classes with learners at practically any level of English proficiency. For these reasons, "themebased courses enjoy wide popularity in today's ESL curricula in elementary, 
secondary, and post secondary settings..." (p. 28).

A less common model of content-based instruction used in peace education ESL/EFL classes, discussed by Oxford (1993), is English for Specific Purposes (ESP). This approach "selects and teaches language material for chosen settings: medicine, engineering, commerce, hotel management, science, and so on" (Oxford, 1993, p. 79).

In a content-based course what types of materials are used, what skills are taught and in what order? "Theorists and practitioners have suggested as a starting point the use of authentic texts which are relevant to the learners' second language needs---i.e., written or oral texts which were created for a purpose other than language teaching" (Brinton, Snow \& Wesche, 1988, p. 1).

Mohan (1986), who defines content and language as being inseparable, proposes the construction of a "knowledge framework for activities" in order to aid students in their development of language and thinking skills. Students must first be aware of the skills needed for an activity. The use of visuals allows for students to access what skills they have and what skills they still need to develop in order to perform the activity. Visuals, such as tables and charts, are used to aid students in gaining the necessary awareness and skills.

Within the knowledge framework, there is "specific, practical knowledge and general, theoretical knowledge" (Mohan, 1986, p. 46). Practical knowledge, that which deals with the "here and now," should be addressed before students begin to deal with theoretical knowledge. Mohan (1986) asserts, "While context-dependent 
practical discourse is important for the early stages of language learning, competence in processing relatively context-independent theoretical discourse is necessary for academic achievement and is a major aim in schooling" (p. 101).

As discussed above, research indicates that a content-based approach to teaching English as a second/foreign language allows learners to increase their level of proficiency at a faster rate than when language is taken out of context and the focus on form takes precedence. With theme-based courses being the most widely used among the three models discussed by Brinton, Snow, and Wesche (1989), the question then remains what themes should be taught? Commonly in theme-based courses, learners have a variety of academic interests. Brinton, Snow and Wesche (1989) suggest that teachers conduct a needs analysis as well as considering their own interests.

In addition to the content-based approach being a focal point of teachers and researchers at the beginning of the 1990s, Brown (1991) mentions student empowerment, the teaching of global issues, and cooperative, learner-centered methods. A common thread that seems to run through the issues mentioned by Brown (1991) is a return to humanistic teaching, with a concern for the welfare of each student and the class as a whole. With content-based approaches making their way into more and more second and foreign language classes, the likelihood of ESL/EFL teachers coming into contact with peace issues is increasing. 


\section{TESOL's Link with the United Nations}

These trends in the field of teaching English to speakers of other languages are consistent with the development of TESOL's relationship with the United Nations. There appears to be increased concern among ESL/EFL educators to become involved in modeling a peaceful world in the language class.

Since the spring of 1990, the organization of Teachers of English to Speakers of Other Languages (TESOL) has been a Non-Governmental Organization (NGO) of the United Nations' Department of Public Information and now has a responsibility to contribute to increasing the public's understanding of the UN and its programs and to promote the goals of the agency (TESOL and the United Nations: A new partnership, 1990). TESOL's liaison to the United Nations, Larson (1992), explains, "TESOL members can have much more influence in local school and community actions than one liaison has at UN headquarters in New York" (p. 19). Larson emphasizes the importance of teacher preparation programs to educate teachers about the issues dealt with at the United Nations, such as peace, justice, and sustainable development. She suggests that materials writers also need to be involved in developing curricula to support these changing needs. Larson further adds that in the ESL/EFL class, teachers can become involved by educating students to become world citizens. In order to carry out the responsibilities that TESOL now has as an NGO of the United Nations, cooperation and action on all levels within the field is needed.

Ashworth (1991) discusses what the organization of TESOL and individuals 
can do to act as advocates for peace, language rights, and education (p. 231). She indicates that as advocates for peace, ESL/EFL educators can develop in students an awareness and the skills of mediation, cooperation, and negotiation. Teachers should also act as advocates for the rights of children to develop and maintain their first language. As an organization, TESOL can play a role of educating communities about issues such as bilingualism. Ashworth (1991) asks, "Does TESOL have a responsibility to listen and to speak, to inform, to enlighten, and to a certain extent, to guide public opinion, as well as to make itself accountable to it?" (p. 236).

The issues discussed by Ashworth (1991) point towards the increasingly global role that TESOL is playing. Already ESL/EFL language teachers have begun thinking, writing and speaking out on the need and responsibility of the field to promote the goals of the United Nations Educational Scientific Cultural Organization (UNESCO), which works in cooperation with language teachers around the globe.

In the introduction to Language Teaching in a World without Peace, NeuAltenheimer (In Raasch, 1993) explains the goals of UNESCO.

The purpose of the United Nations Educational, Scientific and Cultural Organization as enshrined in its Constitution proclaimed in 1945 is to contribute to peace by promoting collaboration among the nations in order to further universal respect for justice for the rule and law and for the human rights and fundamental freedoms which are affirmed for the peoples of the world, without distinction of race, sex, language or religion..... (p. 11)

Gomes de Matos (1988) discusses UNESCO's efforts to bring together the fields of language teaching and peace education. 
...[O]ne of the recommendations made by UNESCO experts at a conference [held in 1987] on the content and methods of teaching of foreign languages and literatures for peace and understanding at Kiev University, [former] USSR, stressed the need for 'relevant international non-governmental organizations to organize, in cooperation with UNESCO, meetings of experts to prepare training seminars and workshops for teachers of foreign languages and literatures in the spirit of peace and understanding among nations'. (p. 16)

Following this conference, Gomes de Matos (1988) notes that a group of applied linguists in Australia formed a working group focusing on language and peace. He adds that the theme of the 1990 Congress of the International Association of Applied Linguistics (AILA) was “Applied Linguistics, International Understanding, and Peace Education" (Gomes de Matos, 1988, p. 16).

\section{The Expanding Role of the ESL/EFL Teacher}

Larson (1990) discusses how TESOL and its members might contribute to a greater understanding globally. She explains that already teachers use classroom techniques which promote cooperation and sensitivity of cultural differences. How can teachers expand their role? What level of awareness do ESL/EFL teachers have of the root causes of misunderstandings and how to solve conflicts peacefully? "Communication is the key to many solutions for global difficulties, and we are communication specialists" (Larson, 1990, p. 21). Are teachers prepared to teach these issues in the classroom?

As an NGO of the United Nations, TESOL now has the responsibility to play a greater role in promoting the creation of a more peaceful world. How is TESOL as an 
organization preparing its members? Since 1990, in response to the interest in peace education shown by participants at the 1989 TESOL conference in San Antonio, Texas, TESOL's Committee on Sociopolitical Concerns has had a subcommittee on International Understanding headed by Anita Wenden. "Many ESL and EFL professionals have responded positively to the notion that foreign and second language educators have a role to play in educating towards the achievement of a peaceful world. Others are curious" (Wenden, 1990, 1).

For several years TESOL educators in the state of New York have been meeting about once every two months (New York Peace Education Seminar) to prepare themselves for teaching peace education in their ESL classes as well as to increase "interest in this area throughout the ESOL field" (Fox, 1992, p. 7). Other states currently involved in promoting peace education through their TESOL special interest groups include California, Washington, and Hawaii. Efforts are still being made to form a Peace Education Interest Section in TESOL.

As mentioned by Brown (1991) TESOL professionals are shifting the focus of their teaching and research concerns toward sociopolitical issues, developing curricula that are more content-centered and task-based, with an emphasis on teaching global issues, as well as empowering students by using more cooperative, student-centered teaching methods.

The expanding role of the ESL/EFL teacher is recognized by Jacobs (1990) who explains that, although the primary job of ESOL teachers is to help students 
improve their English, teachers can also foster international understanding among their students by introducing themes of a global nature, such as "change, communication, commonality, and diversity, human ability to impact the future, and interdependence" as well as introducing the skills necessary for gathering and processing information as well as understanding people from other cultures (p. 27).

EFL teacher Freudenstein (1993) emphasizes that second and foreign language teachers should expand their role to include the teaching of peace education:

Teaching a foreign language means preparing people for communication not only across linguistic borders, but also across cultural and ideological borders. This can only work if our students are willing to meet and accept others in a truly humanistic way. Therefore it should become standard procedure to include peace education as an explicit learning goal in all foreign- and second-language curricula. (p. 78)

Commonly used in peace education ESLEFL classes are humanistic approaches to language teaching. Baldwin (1992) carried out a pilot study on student attitudes in adult ESL classes taught by instructors who identify themselves as humanistic teachers. The most striking finding from the study, Baldwin explains, is that all of the subjects agreed or strongly agreed with the statements, "I learned more English from this teacher than from my other teachers at ALC [American Language Center]" and "I feel more comfortable in this teacher's class than in any other class at ALC" (p. 15). From this study, Baldwin concludes that "humanistic teaching practices have a marked effect upon both the emotional and academic development of such students...[with] an increase in their self-esteem...[and] increased motivation" (p. 15). 
According to Reardon (1988), teaching about human rights is a part of peace education. Peterson (1990) discusses the responses of her upper-intermediate/ advanced ESL students to a reading and writing course with a human rights focus, designed by herself and a colleague: "I found that our students were highly motivated by the topic and by the 'realness' of the subject matter and examples" (p. 28).

One of the skills taught in peace education classes is critical thinking. Vandrick (1996) explains that teaching critical reading and thinking skills increases ESL students' awareness of how language can sometimes be used to "manipulate and even deceive" the reader (p. 29). She cites as an example the use of euphemisms, such as "downsizing," as a way "to sugarcoat negative situations" (p. 29). Vandrick (1996) also points out that the passive voice is sometimes used to "avoid assigning or taking responsibility" (p. 30). A third example of how language can be used to manipulate or deceive is labeling, such as using peace-related words, "peacekeepers" for weapons, to "disguise or 'soften' violence and war" (Vandrick, 1996, p. 30). Vandrick (1990) concludes, "If students develop their critical thinking and reading abilities, they will be far readier to deal with the world they face and to have a positive impact on that world and on its prospects for peace" (p. 35).

Another skill taught in peace education classes is nonviolent conflict resolution. Fine (1990) discusses how the curriculum of Educators for Social Responsibility (ESR) can be applied to the ESL class for teaching creative conflict resolution. The teaching/learning strategies in ESR's curriculum, applicable to the 
ESL context, "include: 1) Semantic mapping (the web); 2) Personal experiencesharing in pairs or groups of 3-4; 3) Role-plays; 4) Guided imagery; 5) Cartoons; 6) Singing; 7) Future newspaper headlines" (p. 19).

After integrating peace issues into an ESL writing class, Fox (1990) comments on the reactions of his students: "All the students became more informed about issues related to world peace, became intensely involved in animated discussion, and produced well-supported essays" (p. 19).

\section{Conclusion}

This chapter has discussed definitions of peace education, highlighting the fact that disagreement over terminology still exists due to the fact that peace education is a new field. A brief historical overview was given of the events which lead to the development of the field of peace education. Following, objectives of peace education, both inside and outside the context of ESL/EFL classes, were discussed. Arguments in the debate over the appropriateness of peace education for the ESLEFL class were given in the second section of this chapter. Finally a rationale for teaching peace education in ESL/EFL classes was discussed, in light of the changes taking place in field of teaching English to speakers of other languages.

The efforts being made by many ESL/EFL educators to incorporate peace education into second and foreign language teaching are evidence that awareness about 
peace issues is increasing. These teachers have a genuine concern about the state of the planet and have made a conscious decision to move beyond the traditional role of the ESL/EFL teacher to a broader role of educator, one who prepares students to become "participative, well-rounded citizens, not specialized cogs" (Jacobs, 1993/1994, p. 15).

This study addresses the following questions which arose in the review of the literature. Are teachers and students interested in peace education? Why should ESL/EFL educators be concerned with empowering their students, encouraging cooperation in the classroom, or teaching issues that increase students' awareness of the world around them? How does the world that a teacher models inside the class influence the world beyond the four walls of the classroom? How are teachers integrating the methods, content and skills of peace education in their ESL/EFL classes? 


\section{CHAPTER III}

\section{METHODOLOGY}

This chapter focuses on subject recruitment, gives a description of the subjects, and outlines the procedures carried out for designing the instruments. Following, is a discussion of validity and reliability as well as the procedures for collecting and analyzing the data. The researcher's original plan to carry out a case study on one ESL class in order to examine student attitudes toward peace education had to be changed due to difficulties discussed below. The direction of the study then turned toward an exploration of broader issues involved with teaching peace education in ESL/EFL classes, for which a survey design was chosen. According to Nunan (1992), “The purpose of a survey is generally to obtain a snapshot of conditions, attitudes, and/ or events at a single point in time" (p. 140). For this study, questionnaires, designed by the researcher, were used to collect qualitative and quantitative survey data from a convenience sample of thirteen ESL/EFL teachers and seventy ESL/EFL students.

\section{Description of Subjects}

It was first planned to carry out a case study in order to examine the attitudes of 
one ESL class toward peace education. The researcher predicted that the best way to investigate whether or not ESL students are interested in peace issues and comfortable dealing with these issues is to observe students in the context of their ESL class over a period of two to three weeks. The first procedure involved finding an ESL class which incorporated peace education into the methods and curriculum. With the field of peace education still being new and definitions of peace education varying, it was difficult to identify ESL classes with a peace education focus. As an initial strategy, the researcher sought out ESL classes using the textbook Making Peace: A Reading/ Writing/ Thinking Text on Global Community (Brooks \& Fox, 1995), only to find out that although the authors explicitly state that it is a textbook with a "peace education" focus, it could not be assumed that the selection of this text was for the purpose of teaching peace education. Those instructors contacted who were using Making Peace (1995) explained to the researcher that they would not consider their ESL class to be one with a "peace education" focus; furthermore, the teachers mentioned that they would feel uncomfortable being labeled peace educators.

The next strategy for locating an ESL class for the case study was to send a message to the Teachers of English as a Second Language List (TESL-L), requesting the participation of ESLEFL educators teaching peace education. This proved to be a much more effective strategy. Within a week, several enthusiastic responses from around the world were sent to the researcher's e-mail address. Most of the respondents were located too far from the researcher for a case study to be a financially 
viable option; therefore, a survey was carried out instead.

Subjects for the teacher survey were recruited in three ways: 1) by sending a message to the Teaching English as a Second Language List (TESL-L) on the Internet, requesting the participation of ESL/EFL educators currently teaching peace education or planning to; 2) by having articles published in two newsletters with a peace education in language teaching focus; and 3) by sending Teacher Surveys directly to ESL/EFL teachers with an interest in peace education. In addition, one participant volunteered to hand out copies of the Teacher Survey to other potential subjects at the 1996 TESOL conference. In total thirteen teachers, seven ESL and six EFL, agreed to participate. From the pool of thirteen subjects, four agreed to ask their students to participate in the student survey.

The teacher survey was carried out with seven ESL and six EFL teachers in classes where peace education was either the central theme or a sub-topic. Student survey data were collected in four ESL/EFL classes, with a total of seventy participants. Three EFL classes (in Israel, Italy, and Japan) and one ESL class in Oregon, United States agreed to participate. In the three EFL classes, peace issues was the main theme. The ESL class addressed global issues as the central theme and peace issues as a sub-topic.

\section{Teacher Survey Participants}

The criteria for selecting the teacher subjects for this study was that they teach, 
or plan to teach, peace issues as the central theme or a sub-topic in an ESL/EFL class. All teachers meeting these criteria were included in the study as well as one teacher who did not teach peace by incorporating peace issues into his ESL class, but rather by creating a peaceful atmosphere in his class. Table 3.1 shows the convenience sample of thirteen subjects obtained for the teacher survey.

TABLE 3.1 TEACHER SURVEY PARTICIPANTS

\begin{tabular}{|ll|lc|}
\hline ESL Teachers (All in the U.S.) & & EFL Teachers & \\
\hline California & 2 & Israel & 2 \\
Hawaii & 1 & Italy & 1 \\
New York & 2 & Japan & 2 \\
Oregon & 1 & Russia & 1 \\
Wisconsin & 1 & & 6 \\
\hline TOTAL & 7 & TOTAL & \\
\hline
\end{tabular}

Note: For some teachers there is no one to one correspondence between his/her country of origin and the current location of employment.

A description of the seven ESL and six EFL teachers and their students is given below. The depth and breadth of the teacher survey responses varied greatly. With the information provided, the researcher aims to paint as accurate a picture as possible of each teacher and his/her class. Those teaching locations marked with an asterisk “*” indicate the classes which participated in the student survey; for these four classes, a description of the teacher is given below and the students are described under Student Survey Participants. 


\section{ESL Teacher Participants}

California. This teacher states that she reflects on her ESL teaching experiences at a university in Wisconsin as she answers questions on the Teacher Survey. Currently she is a teacher trainer in an MA: TESOL Linguistics program in California. She has written articles and given conference presentations on teaching peace education in ESL classes.

California. At this university-based language institute, this subject works as an ESL teacher and the program director. This teacher explains that his way of teaching peace education involves creating a comfortable atmosphere for students, but not explicitly incorporating "peace" as a topic in the class. His students are from a variety of countries.

Hawaii. This ESL teacher works at a Japanese college in Hawaii, where all of the students are from Japan. She describes her students as being "resolutely propeace." This teacher's own interest in peace education stems from her personal experiences as a child in World War II and as a participant in the Civil Rights Movement in the 1960s.

New York. A former Peace Corps volunteer and advocate of immigrant rights, this ESL teacher has written about and presented on teaching peace education in ESL classes. At the time of the survey, he was not teaching an ESL class.

New York. This teacher works with immigrant ESL students from every continent in the world. On the Teacher Survey, she writes about her concern for the 
survival of American society as her reason for wanting to teach peace education. She explains, "I believe that the multiculturalism movement has done its level best to tear this country apart...."

Oregon*. When responding to the question of why she had chosen to teach peace education in her advanced-level reading class, this ESL teacher responded, "I did not choose to teach peace education. The book Making Peace (1995) was recommended to me.... [It] was an appropriate book because the themes fit into the global topics focus and the articles are an appropriate level of difficulty." She explained to the researcher in a conversation that while she shares many of the same values which peace educators hold, she would not refer to herself as a peace educator. "If I say I am a Peace Educator, my focus shifts from concern about [my ESL students'] language skills to concern about their understanding of peace issues." For a description of this teacher's students, see Student Survey Participants below.

Wisconsin. This ESL teacher works at a language institute with students from primarily Japan, but also Korea, Russia, Ukraine, and Indonesia. In her class, "peace" is introduced as a sub-topic; she "tries to incorporate small bits and ideas into lessons/ drills that get the students to expand their thinking."

\section{EFL Teacher Participants}

Israel $^{*}$. In her definition of peace education, this EFL teacher comments that, "peace education is the teaching of tolerance and acceptance of all mankind. It also 
has to stress living side by side and overlooking any differences and learning from these differences." In Israel, talking about peace is "part of everyday life." She explains that her junior high school students have a lot to say about peace. The most popular topic of discussion is Israeli/ Arab relations. For a description of this teacher's students, see Student Survey Participants below.

Israel. This EFL teacher works with school children between the ages of 13 and 17. She uses a variety of authentic materials to teach about social and personal (rather than global or political) issues. The topics she addresses in her class include: religious values, traditional dress and customs, intergenerational issues, as well as ethnicity and diversity.

Italy*. The teacher of this upper intermediate/ advanced EFL class for medical students at a university in northern Italy is involved with teaching and researching peace issues both inside and outside of the language class. He is active in a number of peace and human rights organizations as well as continuing to write and present on peace education. In this EFL class, he focuses on five central peace issues which were selected by the students at the beginning of the semester. For a description of this teacher's students, see Student Survey Participants below.

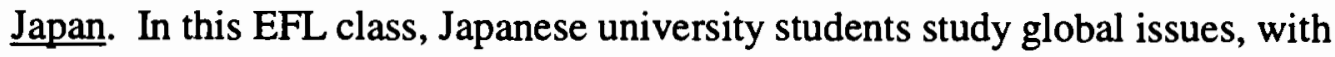
peace as a sub-topic. The teacher is a member of the Global Issues in Language Education Special Interest Group of the Japan Association of Language Teachers (JALT), from which he draws many of the ideas for his classes. He is also involved in 
training junior and senior high school teachers how to incorporate global issues into their EFL classes.

Japan*. This EFL teacher's interest in teaching peace education in ESOL classes was inspired by a graduate course she took from Betty Reardon at Columbia Teacher's College in New York. For the Teacher Survey, she commented on her EFL ('First Year English') class for International Studies majors at a Japanese university. This mixed-skills, content-based class integrates "peace" as one of three central themes. In addition to teaching peace education in her EFL classes, she is involved in materials and curriculum development of classroom activities with a peace issues focus. She has also given presentations at language teacher conferences on teaching peace education. Currently she is working on establishing a women's literacy and development program in India. For a description of this teacher's students, see Student Survey Participants below.

Russia. This teacher is planning to teach peace education in an adult EFL class. In preparation for this class, she has begun researching the content and methods of peace education, as well as analyzing in detail her own approach to teaching. She is also planning on writing her Master of Arts thesis on the topic of teaching peace education in EFL classes.

\section{Student Survey Participants}

Subjects for the student survey were recruited by asking the thirteen teacher 
participants if they would be willing to have their students involved in a survey of students' perspectives toward the teaching of peace education in ESL/EFL classes. A convenience sample of seventy subjects from eight countries was obtained.

TABLE 3.2 STUDENT SURVEY PARTICIPANTS

\begin{tabular}{|c|c|c|c|c|c|c|c|}
\hline \multicolumn{2}{|c|}{$\begin{array}{l}\text { EFL Class } \\
\text { Israel }\end{array}$} & \multicolumn{2}{|c|}{$\begin{array}{l}\text { EFL Class } \\
\text { Italy }\end{array}$} & \multicolumn{2}{|c|}{$\begin{array}{l}\text { EFL Class } \\
\text { Japan }\end{array}$} & \multicolumn{2}{|c|}{$\begin{array}{l}\text { ESL Class } \\
\text { Oregon, U.S. }\end{array}$} \\
\hline Israel & 18 & $\begin{array}{l}\text { Greece } \\
\text { Italy }\end{array}$ & $\begin{array}{r}1 \\
11\end{array}$ & Japan & 31 & $\begin{array}{l}\text { Iran } \\
\text { Japan } \\
\text { South Korea } \\
\text { Taiwan } \\
\text { Thailand }\end{array}$ & $\begin{array}{l}2 \\
4 \\
1 \\
1 \\
1\end{array}$ \\
\hline TOTAL & 18 & TOTAL & 12 & TOTAL & 31 & TOTAL & 9 \\
\hline
\end{tabular}

Among the four participating classes, there were differences in the type of program, in the level of English proficiency of the students, as well as in the students' cultural and language backgrounds and their age. For this reason, the results from this study are not generalizable to other populations. This section of the study aims to provide a glimpse into four ESL/EFL classes which all have in common the incorporation of peace education as either the central theme or a sub-topic. Below is a description of each of the classes which participated in the student survey.

The first group of subjects studied in a compulsory EFL class for eighth graders in Israel. In the year that this class was taught, the national theme of Israel was 
peace. The ministry of education in Israel designed a curriculum and published materials on peace education. Each teacher was free to design his/her own course. Before this year-long course began, students were aware that they would be "learning English through different activities based on or dealing with peace". The subjects ranged in age from 12 to 14 , with most being 13 years old. Participants from this class included seven females and eleven males.

The second class that participated consisted of EFL students studying in an upper intermediate/ advanced ESP (English for Specific Purposes) EFL class for first, second and third year medical students at a university in northern Italy. Students in this class studied five peace education topics related to medicine which were selected by the students at the beginning of the term. The youngest student was 18 , the oldest 22, with the majority being 19 years old. A total of five females and seven males completed the Student Survey.

The third class was an intermediate-level, content-based EFL class, required for International Studies majors at a Japanese university. This course was the second semester of a year-long, integrated-skills 'First Year English' class. The themes addressed were: 'countries,' 'environment,' and 'peace.' Ages of the subjects ranged from 18 to 23, with the majority being 19 years old. In total, twenty-two females and nine males participated.

Subjects from the ESL class studied reading at the advanced level in an intensive language program designed to prepare students for academic classes at a 
university in Oregon, United States. This class had a global issues focus, with peace as a sub-topic. The ages of the students ranged from 21 to 51 , with most of them being 23 or 24 years old. There were a total of six females and three males.

\section{Instruments}

In order to “...obtain a snapshot of... attitudes... at a single point in time" (Nunan, 1992, p. 140), a survey was carried out, using questionnaires designed by the researcher. Design of the questionnaire for the teacher survey was relatively unproblematic, while developing the questionnaire for the student survey presented some obstacles. The researcher predicted that the respondents of the Teacher Survey would be native or native-like speakers of English, and therefore have little difficulty understanding the questions. Only the information obtained in the pilot study of five advanced ESL students from Italy, Japan, and Taiwan, studying global issues, could be used when designing the first version of the EFL Survey (EFL I Survey). Data collected in the first two EFL classes were used to revise the Student Survey, taking into consideration issues of English language ability. Issues of cultural background could be considered only to a very limited extent (based on the pilot study findings) when designing the Student Survey.

The questionnaire for the teacher survey consisted of eight open questions, which asked teachers to comment on how they define peace education, how and why 
they teach peace education in their ESL/EFL class and how their students responded. The aim of the teacher survey was to examine the range of responses from teachers. For example, do all ESL/EFL teachers surveyed define peace education in the same way? Or, is there variation in their definitions of peace education, as found by Bjerstedt (1994) in interviews with fifty peace educators from twenty-two countries. Another question addressed on the Teacher Survey includes the rationale of ESL/EFL educators for teaching peace education in their classes. Are there themes that seem to emerge in the responses given? Is peace education just another theme for a contentbased class? What might these respondents have in common with regard to their reasons for teaching peace education? Thirdly, the Teacher Survey aims to gather information on how the respondents incorporate peace education into their ESL/EFL classes? In what ways are the respondents' approaches to teaching peace education in the ESL/EFL class similar and in what ways are their approaches different? Lastly, the Teacher Survey elicits comments on how these teachers' students responded to the class.

The questionaire for the student survey was pilot tested with five advanced ESL students who had studied global issues. The subjects recruited were from Italy, Japan, and Taiwan. Using the suggestions made by these subjects, the researcher created the first version of the EFL Survey.

The Student Survey included open and closed questions (Likert-type items, forced choice questions, and rankings), with 17 items on each of the EFL versions and 
19 items on the ESL version. All items on the EFL II and ESL Surveys are identical, with the exception of two demographic questions that appear only on the ESL version. Demographic questions on the EFL I and EFL II Surveys were addressed in items 1-6. ESL participants provided demographic information on items 1-8.

Research questions addressed by the student survey include: 1) Do any patterns emerge when examining the group of student subjects who show the greatest interest in peace education; 2) Do any patterns emerge when examining the group of student subjects who show the least interest in peace education; 3) Which materials do students find the most interesting and the most useful for improving their English; and 4) Which activities do students like the most and find the most useful for improving their English?

On the first version of the EFL Survey, eight open questions appear, of which five focus on central issues in the study. Nunan (1992) asserts that although responses from closed questions are easier to analyze, open questions often yield responses that are more useful. On the other hand, in cases where time for filling out the survey is limited and/ or English proficiency of the subjects is low, the use of open questions is not advantageous. After the first two participating classes had completed the first version of the EFL Student Survey, the researcher examined the data and determined that further revisions to the EFL Survey were necessary. For the first class (the EFL class in Italy) that completed the Student Survey, time was a limiting factor. For the second class (the EFL class in Israel), it appeared that the level of English proficiency 
may have limited subjects' ability to express their opinions on the open questions. A second version of the EFL Student Survey, containing fewer open questions, was then created.

The EFL I Survey includes eight open and nine closed questions (one question with 5-point Likert scales and eight forced choice questions). The EFL II Survey consists of three open and fourteen closed questions (five questions with 5-point Likert scales, four forced choice questions, and five questions with rankings). On the ESL Survey, four open and fifteen closed questions appear (five questions with 5-point Likert scales, five forced choice questions, and five questions with rankings). (The EFL I, EFL II and, ESL Student Surveys can be found in Appendix B.)

Items 7 and 8 on the EFL I Survey elicited responses on subjects' interest in and comfort with peace issues at the beginning of the semester (item 7) and at the end of the semester (item 8). These questions focused on the affective dimensions (comfort) in the language class as well as motivation (interest). In one of the first two participating classes, only 3 out of 12 respondents selected the terms "comfortable"/ "uncomfortable" to describe how they felt at the beginning and/or end of the semester; thus, little information on the affective dimensions was obtained from that class. Therefore, on version II of the EFL survey "comfort" and "interest" are dealt with in separate questions. On the EFL II Survey, a 5-point Likert scale is used (with "somewhat interested/ comfortable" at the middle point) to allow subjects to indicate the degree to which they felt comfortable and interested. 
Item 9 on the EFL I Survey is a closed, "yes-no" question that asks subjects: "Do you think that you were able to improve your English skills by talking/ reading/ writing about Peace Issues in your EFL class?" With content-based classes typically being mixed-skill, teaching listening, speaking, reading and writing, a re-forming of the question was necessary in order for the study to elicit responses on the improvement in each specific skill area. On the EFL II Survey, this item includes one 5-point Likert scale for each skill area, using the labels "improved a lot", "improved", “improved somewhat", “improved very little", "didn't improve”.

Items 10 and 11 , open questions which focus on students' interest/ disinterest in the peace issues taught in their class, were combined into one item, a ranking, on the EFL II Survey. The ranking provides data on what students thought about one peace issue in relation to another.

The next item changed on the EFL I Survey is number 12, a closed, "yes-no" question: "Did any of the Peace Issues that you studied have an effect on you?" In the first two groups of subjects to fill out the EFL Student Survey, only 5 out of 30 respondents indicated which peace issue had an "effect" on them. Responses of "yes" or "no" on this item with no explanation provided little useful information. On the EFL II Survey, subjects indicate which of the four categories of "peace issues" (development, environmental, human rights, or peace issues) had an effect on them by marking a check $(\checkmark)$ next to that item. The "peace issue" categories may be confusing to subjects, considering that "peace" is listed as a category under "peace 
issues." At the time that the instruments were designed, the researcher understood "peace education" to be a term which could be used interchangeably with "global education," which deals with development, environmental, human rights, and peace issues (Cates, 1992). While it is the case that many educators do use these terms interchangeably, as indicated by Cates $(1992$, p. 3), peace educator and researcher Reardon (1988) defines peace education as having three branches, namely “development, environment, and human rights"; consequently, the researcher proposes a final version of the Student Survey (see Appendix C) with items designed according to Reardon's definition of peace education.

Subjects' attitudes toward the activities in their ESLEFL class were the focus of item 13 on the EFL I Survey. This item was changed from 5-point Likert scales for each activity to a ranking, so that more could be learned about what the respondents thought about the activities in relation to one another.

Question 14 on the EFL I Survey asks subjects to indicate which materials were used in their respective classes. This question was included on the EFL I Survey in order to clarify for the respondents what was meant by "materials" before they answered the open questions to follow. In the pilot study, all subjects mentioned that they did not understand what was meant by "materials." The six categories of materials (articles from human rights, environmental, and development organizations, films/ videos, literature, newspaper articles, songs, textbook) listed in item 14 were taken from responses on the first seven Teacher Surveys completed. In total, these 
teachers used ten different types of materials. The six materials that appear on the Student Survey are those which were listed by two or more of these teachers. Item 14 was not included on the EFL II Survey due to the modification of the open questions 15 and 16, "Which materials were interesting?" and "Which materials were uninteresting?" respectively, to a ranking that listed the six categories of materials.

The final question on the EFL I Survey is an open question which asks subjects to list the materials that helped subjects to improved their English. This item was changed to a ranking on the EFL II Survey.

\section{Validity and Reliability}

This is the first study, to the researcher's knowledge, to be carried out on teachers and students of peace education ESL/EFL classes; consequently, it was necessary for the researcher to design the instruments for the Teacher and Student Surveys. A non-random sample of thirteen ESL/EFL teachers and seventy students was obtained. There was only one variable that could be controlled in the sample of teacher subjects recruited, namely that they be teaching or planning to teach peace issues as the central theme or a sub-topic in an ESL/EFL class. The single variable that was controlled for the group of student subjects was that they be studying peace issues as the central theme or a sub-topic in an ESL/EFL class. Issues of cultural background and English language proficiency of the subjects could be considered only 
to a limited extent, due to the fact that only one variable was controlled. The range of subjects recruited was broad; therefore, results from this study are not generalizable to other populations.

According to the responses received on the Teacher Survey, it appeared that most of the survey items measured what they were intended to measure. The survey items which did not appear to have face validity include those focusing on how teachers incorporate peace education in their ESL/EFL classes. These items seemed to measure only part of what they were intended to measure. External reliability of the Teacher Survey cannot be determined since the instrument has not been used on any other populations outside this study. As far as analysis of the Teacher Survey data is concerned, only the researcher for this study examined the results; therefore, there is no interrater reliability.

More than one version of the Student Survey was used to collect student data. The first two participating EFL classes completed the EFL I Survey, which was later revised. On the EFL II and ESL Surveys (identical on all items, with the exception of two additional demographic questions on the ESL version), fewer open and more closed questions appear. The rationale for this revision is twofold: 1) less time is required to complete closed items; and 2) closed items are easier for subjects of low English proficiency to answer. These two issues arose when the data from the first two EFL classes were analyzed. Due to the difficulties in recruiting enough subjects for the student survey, the EFL I Survey results, instead of being used as a second pilot 
test, were included in this study. Because of this, the results from the EFL I Surveys could not be compared with the results from the EFL II and ESL Surveys. Only the researcher examined the data from the EFL I, EFL II, and ESL Surveys; therefore, there is no interrater reliability.

With regard to face validity of the Student Survey questions, some items seemed to measure what they were intended to measure, while other items did not. The survey items which seemed to cause confusion for subjects included the Likert scales and rankings, because of the values having been alternated. For these items there is no face validity, as the examples below illustrate. For the ESL Survey, the researcher was present and could explain any unclear items. Despite this, it was evident from one ESL subject's responses that alternating the positive and negative labels on the Likert scales caused confusion. All of this subject's written comments on studying peace issues were positive; and on the first Likert scale measuring interest (where the most positive label was on the left-hand side of the item), the subject selected "very interested." On the next item measuring interest at the end of the term (with the most negative label on the left-hand side of the item) the subject selected "very uninterested." The written explanation given for the latter survey response was not consistent with the Likert-item label chosen. Alternating the values on the rankings also caused confusion for subjects. On a couple of the EFL Surveys received, initial responses to the rankings were scratched out, with the re-ranking written next to the item. The rationale for alternating the values of the Likert-type items and rankings 
was to ensure that the subjects would not be influenced to select an answer based on what they thought the researcher wanted them to indicate. As discussed above, when time is limited as well as the English proficiency of the subjects, alternating the values on Likert-type items and rankings appears to cause confusion (and perhaps also frustration) for the respondents.

\section{Data Collection}

Each participating ESL/EFL teacher received a description of the study before a copy of the Teacher Survey was sent to him/her. Along with the description, the prospective subjects were given a statement explaining how the data would be used and the fact that their identity would be kept confidential. This information for some subjects was obtained from the articles in the two newsletters or was explained in person by the researcher. A copy of the 8-item questionnaire was distributed by sending it via e-mail or through the postal service, faxing it, or giving it to the teacher personally.

All of the teachers were requested to ask their students to participate in the Student Survey. Three EFL and one ESL teacher agreed to distribute the Student Surveys in their classes. Attached to the front of the Student Survey was a copy of the Informed Consent Form (see Appendix B), introducing the researcher, explaining the aims of the study, how the data would be used, and the fact that participation is 
voluntary and responses would be kept confidential. Surveys in the three EFL classes were group administered by the teacher. The researcher instructed each teacher to have one student in the class be responsible for collecting all of the completed Student Surveys, then put the surveys into an envelope and seal it before returning the Student Surveys to the instructor. This was a requirement of the Human Subjects Research and Review Committee. The sealed envelope, containing the Student Surveys, was then sent by the teacher to the researcher. In the ESL class, the researcher group administered the Student Survey.

\section{Data Analysis}

Teacher Survey data which answer the first two research questions were analyzed using a key word analysis. Key words were used to search for patterns among the responses. From the patterns that emerged, categories of responses were formed. The data answering the third research question was analyzed by presenting all of the materials and all of the activities listed by the Teacher Survey participants. The lists were then examined for overlap that might exist in the types of materials and activities that teachers reported using.

In order to answer the fourth and fifth research questions, which focus on the Student Survey, data from items measuring subjects' interest in peace issues, together with responses to four demographic questions, were analyzed. First the researcher 
looked for patterns within each class, then general patterns were explored between the two classes who responded to the EFL I Survey and between the respondents of the EFL I and ESL Surveys. No comparison could be made between EFL I Survey respondents and EFL I and ESL Survey respondents, because of the differences in the instruments. Subjects from the EFL I Survey "who show the greatest interest in peace issues" included those respondents who indicated that they were "interested" at the beginning and end of the semester. Subjects from the EFL II and ESL Surveys "who show the greatest interest in peace issues" included those respondents who indicated that they were "interested" and/or "very interested" at the beginning and end of the semester. The EFL I Survey respondents "who show the least interest in peace issues" included subjects who indicated that they were "uninterested" at the beginning and end of the semester. The EFL II and ESL Survey respondents "who show the least interest in peace issues" included subjects who indicated that they were "not interested" and/or "very uninterested" at the beginning and end of the semester. Demographic data (country of residence, gender, age, lived outside home country for 3 months or more) of the respondents who showed the greatest and least interest in peace issues were used to explore patterns.

Data from survey items focusing on what subjects thought about the materials used in their class, with regard to interest and usefulness, were analyzed by calculating percentages for each material assessed. The percentages for the responses to the open questions on the EFL I Survey were calculated by dividing the number of subjects who 
indicated a particular material as "interesting" or "useful" by the total number of participants who completed the respective survey item. For responses to the rankings on the EFL II and ESL Surveys, percentages were calculated by dividing the number of subjects who ranked a material "most interesting" or "most useful" (only the extremes of the rankings are calculated) by the total number of participants who completed the respective survey item.

The final research question focuses on subjects' assessment of the activities used in their classes. The data from the survey items eliciting responses on the activities were analyzed by calculating percentages for each activity assessed. The percentages for the Likert-type items on the EFL I Survey were calculated by dividing the number of subjects who rated an activity "liked a lot" or "very useful" (only the extremes are calculated) by the total number of participants who completed the respective survey item. For responses to the rankings on the EFL II and ESL Surveys, percentages were calculated by dividing the number of subjects who ranked an activity "liked most" or "most useful" (only the extremes of the rankings are calculated) by the total number of participants who completed the respective survey item.

In Table 3.3, the correspondence of survey items with the seven research questions is shown. The first three research questions focus on issues answered by Teacher Survey items. The following four research questions focus on students' interest/ disinterest in peace issues, and their assessment of the materials and activities used in their respective classes. 
TABLE 3.3 CORRESPONDENCE OF SURVEY ITEMS

WITH RESEARCH QUESTIONS

\begin{tabular}{|c|c|c|}
\hline RESEARCH QUESTIONS & $\begin{array}{l}\text { SURVEY } \\
\text { TYPE }\end{array}$ & $\begin{array}{l}\text { CORRESPONDING } \\
\text { SURVEY ITEMS }\end{array}$ \\
\hline $\begin{array}{l}\text { How do ESL/EFL teachers define } \\
\text { peace education? }\end{array}$ & \multirow{3}{*}{$\begin{array}{l}\text { Teacher } \\
\text { Survey }\end{array}$} & Item 1 \\
\hline $\begin{array}{l}\text { Why have some ESL/EFL teachers } \\
\text { decided to teach peace education in } \\
\text { their classes? }\end{array}$ & & Item 2 \\
\hline $\begin{array}{l}\text { How do ESL/EFL teachers incorporate } \\
\text { peace education into their classes? }\end{array}$ & & Items 3 , and 4 \\
\hline \multirow{3}{*}{$\begin{array}{l}\text { Do any patterns emerge when } \\
\text { examining the group of student } \\
\text { subjects who show the greatest interest } \\
\text { in peace issues? }\end{array}$} & EFL I & Items $1,2,3,5,7$, and 8 \\
\hline & EFL II & Items $1,2,3,5,8$, and 10 \\
\hline & ESL & Items $1,2,3,6,10$, and 12 \\
\hline \multirow{3}{*}{$\begin{array}{l}\text { Do any patterns emerge when } \\
\text { examining the group of student } \\
\text { subjects who show the least interest in } \\
\text { peace issues? }\end{array}$} & EFL I & Items $1,2,3,5,7$, and 8 \\
\hline & EFL II & Items $1,2,3,5,8$, and 10 \\
\hline & ESL & Items $1,2,3,6,10$, and 12 \\
\hline \multirow{3}{*}{$\begin{array}{l}\text { Which materials do students find the } \\
\text { most interesting and the most useful } \\
\text { for improving their English? }\end{array}$} & EFL I & Items $15,16,17$ \\
\hline & EFL II & Items 16 , and 17 \\
\hline & ESL & Items 18 , and 19 \\
\hline \multirow{3}{*}{$\begin{array}{l}\text { Which activities do students like the } \\
\text { most and find the most useful for } \\
\text { improving their English? }\end{array}$} & EFL I & Item 13 a-f \\
\hline & EFL II & Items 14 , and 15 \\
\hline & ESL & Items 16 , and 17 \\
\hline
\end{tabular}




\section{CHAPTER IV}

\section{FINDINGS}

Qualitative and quantitative survey data were collected using questionnaires which were distributed to teachers and students in ESL/EFL classes with a peace education focus. The participants in the Teacher Survey included seven ESL and six EFL teachers from five different countries. Student Survey participants included seventy students from EFL classes in Israel, Italy, Japan, and one ESL class in the United States.

Teacher responses to the eight-item, open-question survey are presented in the first four sections of this chapter: 1) defining peace education; 2) rationale for teaching peace education; 3) how peace education is taught in ESL/EFL classes; and 4) how students have responded---in the teachers' words. The research questions for this study which relate to the Teacher Survey are addressed in the first three sections. Section four is included in order for a comparison to be made between the teachers' perceptions of the outcomes of their class and the perceptions of their students.

Following the Teacher Survey results, data from the Student Survey are presented in five sections: 1) background; 2) response rate; 3 ) results of survey items measuring interest and comfort; 4) assessment of materials; and 5) assessment of 
activities. The first section provides demographic information on the subjects as well as providing a profile of the four classes. The second section discusses the response rate for each class. Section three presents the results from survey items measuring subjects' interest in and comfort with peace issues at the beginning and end of the term/ semester. On the EFL I Survey, completed by the classes in Israel and Italy, subjects responded to two closed questions measuring interest and comfort. Four items on the EFL II and ESL Surveys, completed by the classes in Japan and Oregon, U.S., respectively, addressed interest and comfort. Section four presents the materials that subjects found most interesting and most useful for improving their English. Lastly, section five presents the activities that subjects liked the most and found the most useful for improving their English.

\section{Teacher Survey}

A Teacher Survey was carried out with thirteen participants, seven ESL and six EFL teachers. Twelve out of the thirteen teacher participants identified themselves as teaching peace as a central theme or a sub-topic in their ESL or EFL class. One respondent, who received a copy of the Teacher Survey from a colleague, emphasized that he did not teach peace directly, but rather indirectly by creating a comfortable atmosphere in his class.

All of the ESL teacher responses were obtained in the United States: 2 in 
California; 1 in Hawaii; 2 in New York; 1 in Oregon; and 1 in Wisconsin. The EFL teachers responded from four countries: 2 from Israel; 1 from Italy; 2 from Japan; and 1 from Russia.

\section{Defining Peace Education}

As discussed in the Literature Review, among peace educators definitions of peace education vary. It was predicted that also among the participating ESL/EFL teachers, variation in definitions of peace education would exist. What did teachers mention in their definitions? Is there overlap among the participating teachers' definitions of peace education?

Table 4.1 shows the categories of responses to the question, "How do you define peace education." In order to compare the participants' responses and search for patterns across their definitions, a key word analysis was performed and the following five categories were created, "skills," "objectives/ goals," "themes/ topics," "attitudes/ beliefs/ values," "methods." The number of subjects, as well as the percent, that responded to each item is listed. Percentages were calculated by dividing the number of subjects who answered with each particular phrase by the total number of participants (13 subjects) who completed this survey item. The highest numbers and percentages of each category are shaded.

The phrase that occurred most often in the respondents' definitions of peace education was "conflict resolution/ conflict management." Thirty-eight percent of the 


\section{TABLE 4.1 TEACHERS' DEFINITIONS OF PEACE EDUCATION}

\begin{tabular}{|c|c|c|}
\hline category & number & $\%$ \\
\hline \multicolumn{3}{|l|}{ SKILLS } \\
\hline conflict management conflict resolution . F, & $p^{5} \%$ & 38 \\
\hline communication & 2 & 15 \\
\hline cooperation & 1 & 1 \\
\hline \multicolumn{3}{|l|}{ OBJECTIVES/ GOALS } \\
\hline activism - is a & $4+4$ & 31 \\
\hline $\begin{array}{l}\text { restructuring communities/ break chain of violence } \\
\text { work throughout one's life for a more peaceful world } \\
\text { be a responsible world citizen } \\
\text { work toward a more sustainable future } \\
\text { challenge prejudice \& discrimination/ work toward a more just world }\end{array}$ & & \\
\hline greater understanding of peace/ awareness of issues threatening peace & 3 & 23 \\
\hline sort out/ deal with problems & 3 & 23 \\
\hline nurture respect, trust, and understanding of human rights & 2 & 15 \\
\hline teach people how to live "with" \& "next to" one another without hatred & 2 & 15 \\
\hline establish atmosphere where people can view each other as equally valuable & 1 & 1 \\
\hline understanding of human condition, capable of good and evil & 1 & 1 \\
\hline \multicolumn{3}{|l|}{ THEMES/TOPICS } \\
\hline $\begin{array}{l}\text { intercultural relations/ understanding \& tolerance of other cultures } f \text { in } \\
\text { human tights justice. }\end{array}$ & $\sqrt{4}+3$ & 31 \\
\hline peace with nature/ environment/ ecology & 3 & 23 \\
\hline personal peace/ being at peace with self & 2 & 15 \\
\hline peace within family/ being at peace with others & 2 & 15 \\
\hline psychology & 2 & 15 \\
\hline economics & 2 & 15 \\
\hline international relations & 1 & 1 \\
\hline history & 1 & 1 \\
\hline literature & 1 & 1 \\
\hline sociology & 1 & 1 \\
\hline any kind of learning activity having a theme of peace & 1 & 1 \\
\hline \multicolumn{3}{|l|}{ ATTITUDES/ BELIEFS/ VALUES } \\
\hline 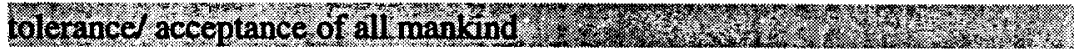 & 3. & 23 : \\
\hline good, moral, spiritual values/ ethical consciousness & 2 & 15 \\
\hline concern for social justice & 2 & 15 \\
\hline respect, appreciation, concern for the environment/ ecological & 2 & 15 \\
\hline consciousness & 1 & 1 \\
\hline responsibility & 1 & 1 \\
\hline $\begin{array}{l}\text { see self and others "clearly"; lose "provincial" and "parochial" attitudes } \\
\text { METHODS }\end{array}$ & 1 & 1 \\
\hline \multirow{2}{*}{\multicolumn{3}{|c|}{$\begin{array}{l}\text { Pesceful classroom methods } \\
\text { cooperative learning } \\
\text { critical thinking/ problem-posing } \\
\text { student-centered methods } \\
\text { cross-cultural learning }\end{array}$}} \\
\hline & & \\
\hline $\begin{array}{l}\text { methods for solving conflict. } \\
\text { humianistic approaches }\end{array}$ & 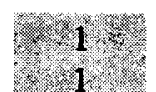 & $1:$ \\
\hline
\end{tabular}


respondents mentioned this phrase, which was grouped by the researcher under the category "skills."

Thirty-one percent of the respondents indicated "activism" as one of the “objectives/ goals" of peace education. One respondent mentioned "restructuring communities and breaking the chain of violence." Another respondent indicated "work throughout one's life for a more peaceful world." A third respondent mentioned the following three phrases in her definition of peace education, "be a responsible world citizen," "work toward a more sustainable future," as well as “challenge prejudice and discrimination and work toward a more just world." The fourth respondent wrote that peace education "should involve an active aspect, which causes some kind of response to the issues dealt with. This may be internal change or active involvement in making a difference for peace."

Listed under the category of "themes/ topics," $31 \%$ mentioned "intercultural relations/ understanding and tolerance of other cultures;" and another $31 \%$ mentioned "human rights/ justice" in their definitions of peace education.

Twenty-three percent of the respondents included "tolerance/ acceptance of all mankind" as "attitudes/ beliefs/ values" to be taught in a peace education class.

Lastly, "methods" were mentioned by three of the thirteen participants. One respondent explains that teaching peace education in the context of an ESL class involves creating peace around oneself. "[T]his means learning and using methods which create a peaceful classroom: cooperative learning, problem-posing, critical 
thinking, student-centered methods, cross-cultural learning, etc.” Another respondent indicated in her definition that peace education involves the use of "methods for solving conflict." A third respondent wrote, "What peace education tries to do is break the negative chain of violence[mentioned above under objectives] and offer learners humanistic approaches to difficult questions which do not leave them feeling like they have no power over their lives."

\section{$\underline{\text { Rationale for Teaching Peace Education }}$}

Teachers' responses to the question "Why have you decided to teach Peace Education in your ESL/EFL class" were quite powerful and are, therefore, presented as quotes, rather than phrases. A key word analysis was carried out in order to explore whether or not patterns existed among the teachers' responses to this item. Six categories emerged from the analysis: "responsibility of the ESL/EFL teacher;" "personally interested in peace issues;" "mission of education;" 'issues are interesting to students;" "peace education was not chosen;" and “methods." Three subjects' responses to this survey item fell under two categories. One subject who discussed a sense of responsibility to teach peace education also indicated a personal interest in peace issues. Another subject who indicated a personal interest in peace issues indicated that peace issues are also on the mind of her students. The third subject, whose response to this survey item fell under two categories, mentioned that “...the language classroom is a perfect atmosphere to bring up issues of international concern 
especially" and "I also believe that the content method has a lot of pluses."

The category of response most frequently mentioned in teachers' answers to this survey item is "responsibility of the ESL/EFL teacher." Each of the five responses listed here discuss the role of the ESL/EFL teacher as one which includes not only helping students to improve their English language skills, but also "develop[ing] in...students good values," "foster[ing] global understanding," "promot[ing] understanding between people of different cultures," helping "[one's] country survive," and "mak[ing] sure...students are aware of all that is involved and what it may mean to have Peace with other countries."

The second most frequent type of response came under the category "personally interested in peace issues." Three subjects expressed a personal interest in peace education when responding to this survey item.

Two respondents discussed the "mission of education." Both subjects seemed to indicate a need for school administrators and teachers to re-examine the goals of education. One subject mentions, "I believe there is a concerted effort from some elements to discourage active learning and the promotion of critical thinking on the part of the students." The second subject writes, "I found a certain purposelessness in the classes here in Japan. Students and administrators wanted to 'level up English,' but there didn't seem to be a WHY attached."

Under the next category of response, "issues are interesting to students," quotes from two subjects are listed. The first respondent indicates that the language class is 
"a perfect atmosphere" for addressing peace education. The second respondent explains that peace is "on the students' minds, in some form or other."

The following category, " peace education was not chosen," includes responses from two teachers who do not identify themselves as peace educators. The first quote listed was made by a subject who creates a peaceful atmosphere in his classes, but does not teach peace education explicitly. The second respondent teaches global issues in her class, addressing peace issues as a sub-topic.

Under the last category of response, "methods," one subject discusses advantages of the content-based approach to language teaching as a rationale for teaching peace education in ESL/EFL classes.

\section{$\underline{\text { Responsibility of ESL/EFL Teacher }}$}

- "As a teacher, I want to develop in my students not just language proficiency but also good values."

- "I have always been an advocate of peace, but as I grew older I began to see the opportunity that ESL teachers have to foster global understanding as something that could not or should not be ignored."

- "To promote understanding between people of different cultures."

- "I teach the way I teach because I am an American and I want to see my country survive. I believe that the multiculturalism movement has done its level best to tear this country apart by encouraging people to ignore one another in all out efforts to be 
different, celebrate that difference and despise others who are different, i.e.

multiculturalism has encouraged xenophobia at levels we never had before."

- "The very notion of Peace is part of everyday life in Israel and as a teacher we have to make sure our students are aware of all that is involved and what it may mean to have Peace with other countries. I think it is important to teach it in an EFL class because all communications done internationally are done in English and the world's view of what is going on here is stated in English."

\section{Personally Interested in Peace Issues}

- "Because it's the most compelling issue in the world right now. Because it's on my mind."

- "Better communication and conflict resolution became important to me on an extremely personal level and bringing it into the classroom allowed me to integrate my work with my personal life in a very satisfying way."

- "A relevant, vital, affective, universal and important topic to deal with."

\section{$\underline{\text { Mission of Education }}$}

- "I believe there is a concerted effort from some elements to discourage active learning and the promotion of critical thinking on the part of the students. There is also an attack on education from administrators and teachers which centers on their apathy toward the mission of education." 
- "I found a certain purposelessness in the classes here in Japan. Students and administrators wanted to 'level up English', but there didn't seem to be a WHY attached.... It then became my goal to establish the WHY's in my classes,...I decided to address issues that affect us all, and try to show students that there are real opportunities for making the world a better place."

$\underline{\text { Issues Are Interesting to Students }}$

- "I think that the language classroom is a perfect atmosphere to bring up issues of international concern especially."

- "Because it's on the students' minds, in some form or other."

\section{Peace Education Was Not Chosen}

- "We do not teach Peace Education as such in our classes."

- "I did not choose to teach peace education. A book Making Peace was recommended to me for my advanced reading class. Making Peace was an appropriate book because the themes fit into the global topics focus and the articles are an appropriate level of difficulty. I don't feel entirely comfortable with the idea of being a Peace Educator in an ESL program.... If I say I am a Peace Educator, my focus shifts from concern about their language skills to concern about their understanding of peace issues." 


\section{$\underline{\text { Methods }}$}

- "I also believe that the content method has a lot of pluses. I like the focus on meaning over form."

\section{How Peace Education is Taught in ESLEFL Classes}

Many of the classes used authentic materials. Three subjects reported using materials from non-governmental development, human rights, environmental, and peace organizations, such as the United Nations Educational Scientific Cultural Organization (UNESCO), United Nations Children's Fund (UNICEF), Amnesty International (AI), and the World Wildlife Federation (WWF). Some respondents created their own materials. Those classes with a required textbook supplemented the curriculum by bringing in authentic materials and realia. There was considerable variation from class to class in the number and type of materials used. Some classes used one or two materials, while others included the use of six or more.

Ten out of the thirteen ESL/EFL teacher participants work with adult learners, mostly university students between 18 and 23 years old. The two teachers working with adolescents were the only respondents who reported using songs, as well as many other authentic materials. One junior high school EFL teacher mentioned that her students had created some of the materials used in her class. One respondent had not yet taught peace education, but was planning to. In the future she plans to use authentic materials, including readings, taped conversations, and lectures "from 
different traditions and geographical locations as much as possible."

\section{Materials Used in ESL/EFL Classes}

authentic materials.

- articles from development, environment, human rights, and peace

organizations

- films/ videos

- literature/ poetry

- newspaper/ magazine articles

- songs/music

- radio/ TV programs

- public service materials

- taped lectures/ conversations

- museum resources

- book of photos

- software/ e-mail

teacher-created peace education materials.

- create own materials using Bloom's taxonomy

- create own materials on global issues in language education

- use materials from the Global Issues in Language Education Special Interest Group of JALT

- use peace education materials published by the Israeli Ministry of

Education (songs, stories, role plays, debates)

textbooks.

- Making Peace: A Reading/Writing/ Thinking Text on Global Community (1995) by Elaine Brooks \& Len Fox

- Face the Issues: Intermediate Listening and Critical Thinking Skills (1997) by Carol Numrich

other materials.

- games

- readers

- posters

- journals

More overlap was found among the classes in the area of activities employed. 
All of the teachers mentioned group discussion as an activity used in their class. Many also had their students engage in debates. Several classes did presentations and role plays/ simulations and had guests give lectures in the class. Having students involved in activities which require cooperation, critical thinking, problem-posing and problem solving, and peaceful conflict resolution were among the most common types mentioned. Some teachers also had their students engage in out-of-class activities as well.

\section{Activities Used in ESL/EFL Classes}

in-class activities.

- group Discussions

- debates

- guest lectures

- role-plays (solve conflicts using WIN-WIN* guidelines)/ simulations

- presentations (individual, group)

- writing (journals, poetry, essays, article summaries)

- poster Sessions

- critical reading/ vocabulary exercises

- complete opinion inventories

- games

- jigsaw exercises

- create videos

- drills

- practical and creative activities (collage, skits, model-making)

- reflect on what can go wrong and "destroy" positive interdependence

- cooperative learning, empathy enhancing, affective-humanistic activities

- Freirean problem-posing

- intercultural awareness and communication (focussing on "species identity")

- any activity requiring students from different backgrounds to work cooperatively

*WIN-WIN refers to a strategy for conflict resolution developed by the Harvard Negotiation Project. (see Fisher \& Ury, 1981) 
out-of class activities.

- research

- interviews

- attend meetings

- group projects

- visits

\section{How Students Have Responded---In The Teachers' Words}

Below are the responses of the four EFL/ESL teachers whose students participated in the Student Survey. These comments are included, as full quotes, in order for a comparison to be made between the teachers' perceptions of the outcomes of their class and the perceptions of their students. What factors do the teachers consider when describing the outcomes? Is there a connection between the teachers' definitions of peace education, their rationale for teaching peace education, and what they write about their students' responses?

\section{EFL Class in Israel}

"Most of the children have a lot to say about peace in general and about peace in Israel specifically. They are more than willing to take part in any lesson that deals with peace."

\section{EFL Class in Italy}

"In a variety of ways, from neo-fascists standing up giving the Nazi salute to others working to create a local Amnesty International group within the university. 
Overall, I think students leave my course with a broader understanding of their world and some mechanisms to deal with its more and more complexed lifestyle. Some students have gone on to be COs [conscientious objectors] to the obligatory National Service, choosing to work in Africa or in immigrant camps; two were volunteers in Bosnia with the Italian Red Cross. Others have refused to change their world-vision. I remember one female student, whose parents are in Opus Dei [a Catholic lay organization], who walked out of class the day we began to discuss AIDS."

\section{EFL Class in Japan}

"Amazingly...if I can go by the students' reactions in their end of the year evaluations. Many of them developed an interest in peace issues, some have gone on work camps to the Philippines, Malaysia and Bangladesh to build toilets, help on farms, etc. Teaching peace issues in my class has enabled me to form a 'virtuous' circle, if I may call it that. Students are interested in these issues, find them relevant, and are spurred on and motivated to work on their language skills."

\section{$\underline{\text { ESL Class in Oregon, United States }}$}

"In general, I think the students really liked the class in that it helped them to feel more confident about their ability to understand articles they are required to read. Some students felt that the constant focus on global issues made the class more serious and 'heavy.' On the other hand, I felt that this focus set a good academic tone to the 
class which inspired students to dig in and work. Several students thanked me at the end of the term for pushing them to work so hard. Students made a strong effort to see how these issues connected to their own lives and for many, it seemed clear that this was the first time they had really talked about these topics with other people. ...I think [they] felt inspired by the idea that each person has the potential for bringing about positive change in the world. They could even see how struggling with English and trying to express their opinions and ideas in class constituted acts of courage."

\section{Student Survey}

Qualitative and quantitative survey data were collected from four groups of ESL/EFL students using questionnaires. Over a period of one year, questionnaires were sent via e-mail, through the postal service or faxed to the respective sites. After the first batch of surveys were returned from Italy and Israel, changes were made to the EFL survey. Chapter 3 describes the changes that were made and why.

\section{Background}

Student Survey participants responded to open and closed demographic questions (items $1-6$ on the EFL versions, items $1-8$ on the ESL version). The questions included age, gender, country of residence, length of time studying English, experience living abroad, intent to complete a university degree and intended major. 
Respondents in the ESL class were asked two additional questions not applicable for the EFL context: "How long have you lived in the United States?" and "Did you study at a college or university in your home country?"

Table 4.2 presents data on the respondents' country of residence, gender, age, and experience living abroad. Data collected on the length of time spent studying English, intent to complete a university degree and intended major are not included here. On the ESL Survey, respondents were asked how long they had studied English

TABLE 4.2 DEMOGRAPHIC INFORMATION

\begin{tabular}{|c|c|c|c|c|}
\hline class & $\begin{array}{l}\text { country of } \\
\text { residence }\end{array}$ & gender & age & $\begin{array}{l}\text { lived outside } \\
\text { home country }\end{array}$ \\
\hline $\begin{array}{c}\text { EFL in } \\
\text { Israel }\end{array}$ & Israel 18 & $\begin{array}{l}\text { Female } \\
\text { Male } 2\end{array}$ & $\begin{array}{lc}12-12 \text { yrs } & 18 \\
18-23 \text { yrs } & 0 \\
24-29 \text { yrs } & 0 \\
30 \text { yrs \& over } & 0 \\
\end{array}$ & $\begin{array}{ll}\text { Yes } & 7 \\
\text { No } & 11\end{array}$ \\
\hline $\begin{array}{l}\text { EFL in } \\
\text { Italy }\end{array}$ & $\begin{array}{lc}\text { Italy } & 11 \\
\text { Greece } & 1\end{array}$ & $\begin{array}{l}\text { Female } \\
\text { Male }\end{array}$ & $\begin{array}{lc}12-17 \text { yrs } & 0 \\
18-23 \text { yrs } & 12 \\
24-29 \text { yrs } & 0 \\
30 \text { yrs \& over } & 0\end{array}$ & $\begin{array}{ll}\text { Yes } & 3 \\
\text { No } & 9\end{array}$ \\
\hline $\begin{array}{c}\text { EFL in } \\
\text { Japan }\end{array}$ & lapan $\quad 31$ & $\begin{array}{lc}\text { Eemale } & 22 \\
\text { Male } & 9\end{array}$ & $\begin{array}{lc}12-17 \text { yrs } & 0 \\
18-23 \text { yrs } & 31 \\
24-29 \text { yrs } & 0 \\
30 \text { yrs \& over } & 0\end{array}$ & $\begin{array}{lc}\text { Yes } & 3 \\
\text { No } & 28\end{array}$ \\
\hline $\begin{array}{c}\text { ESL in } \\
\text { Oregon, } \\
\text { U.S. }\end{array}$ & $\begin{array}{lc}\text { Iran } & 2 \\
\text { Japan } & 4 \times 1 \\
\text { S. Korea } & 1 \\
\text { Taiwan } & 1 \\
\text { Thailand } & 1\end{array}$ & $\begin{array}{lc}\text { Female } & 6 \\
\text { Male } & 3\end{array}$ & $\begin{array}{lc}12-17 \text { yrs } & 0 \\
18-23 \text { yrs } & 4 \\
24-29 \text { yrs } & 3 \\
30 \text { yrs \& over } & 1 \\
\text { No Answer } & 1\end{array}$ & $\begin{array}{lc}\text { Yes } & 9 \\
\text { No } & 0\end{array}$ \\
\hline
\end{tabular}


in the United States. The wording of the question above did not yield data on the total length of time spent studying English; therefore, this information is not included in Table 4.2. The academic interests of the seventy respondents varied greatly and are, therefore, not presented. Only demographic data which could be used to look for patterns among subjects with the greatest and least interest in peace issues are included. All eighteen respondents in the EFL class in Israel indicated that their country of residence is Israel. Eleven of the twelve subjects studying EFL in Italy were residents of Italy, one was a resident of Greece. All of the thirty-one EFL students in Japan were residents of that country. Out of the nine subjects in the ESL class, 4 were from Japan, two from Iran, one from South Korea, one Taiwan, and one was from Thailand. In all four classes there were more male students than female, with the largest gap between genders being in the EFL class in Japan. Subjects in the junior high school EFL class in Israel range in age from 12 to 17; these subjects had studied peace issues in their junior high school EFL class a year and a half prior to filling out the Student Survey. All of the EFL subjects in university EFL classes in Italy and Japan are in the 18-23 age range. In the ESL class, four indicated that they were between the ages of 18 and 23 , three are from 24 to 29 years old, one is 51 years old, and one declined to answer. Most of the EFL students indicated that they had not lived for three months or more outside their home country. All of the ESL students had been studying outside their home country for more than three months.

Table 4.3 presents a profile of the four participating classes focusing on the 
following: the content-based model represented by each class, the theme/s addressed, the setting of the class, the level of English proficiency of the class, the language skills taught, as well as the materials and activities used.

TABLE 4.3 PROFILE OF PARTICIPATING ESL/EFL CLASSES

\begin{tabular}{|c|c|c|c|c|}
\hline features & EFL in Israel & EFL in Italy & EFL in Japan & ESL in U.S. \\
\hline $\begin{array}{l}\text { content- } \\
\text { based } \\
\text { model }\end{array}$ & theme-based & $\begin{array}{c}\text { ESP } \\
\text { for medical } \\
\text { students }\end{array}$ & theme-based & theme-based \\
\hline theme/s & $\begin{array}{l}\text { peace at home } \\
\text { (in Israel), } \\
\text { world peace }\end{array}$ & $\begin{array}{l}\text { human rights, } \\
\text { homophobia, } \\
\text { AIDS,bioethics, } \\
\text { male/ female } \\
\text { communication }\end{array}$ & $\begin{array}{c}\text { countries, } \\
\text { environment, } \\
\text { peace }\end{array}$ & $\begin{array}{c}\text { central theme: } \\
\text { global issues, } \\
\text { sub-topic: } \\
\text { peace issues }\end{array}$ \\
\hline setting & junior high & university & university & university \\
\hline $\begin{array}{l}\text { level of } \\
\text { class }\end{array}$ & intermediate & $\begin{array}{c}\text { upper- } \\
\text { intermediate/ } \\
\text { advanced }\end{array}$ & intermediate & advanced \\
\hline skill/s & mixed & mixed & mixed & reading \\
\hline materials & $\begin{array}{l}\text { films/videos } \\
\text { literature } \\
\text { newspapers } \\
\text { songs }\end{array}$ & $\begin{array}{l}\text { articles } \\
\text { films/videos } \\
\text { literature } \\
\text { newspapers }\end{array}$ & $\begin{array}{l}\text { articles } \\
\text { films/videos } \\
\text { newspapers } \\
\text { textbook }\end{array}$ & textbook \\
\hline activities & $\begin{array}{l}\text { debates } \\
\text { grp. discussion }\end{array}$ & $\begin{array}{l}\text { debates } \\
\text { grp. discussion } \\
\text { guest lectures } \\
\text { research project } \\
\text { role plays } \\
\text { watch movies }\end{array}$ & $\begin{array}{l}\text { grp. discussion } \\
\text { role plays } \\
\text { watch movies }\end{array}$ & grp. discussion \\
\hline
\end{tabular}


Two of the EFL classes and the ESL class are theme-based. Subjects in the EFL class in Italy are medical students, studying English for Specific Purposes (ESP). The themes addressed in the junior high EFL.class in Israel include peace at home (in Israel) and world peace. The subjects in Italy study peace issues in the context of the field of medicine: human rights, homophobia, AIDS, bioethics, and male/ female communication. Environment, countries, and peace are the themes of the EFL class for International Studies majors in Japan. Subjects in the academic ESL reading class focused on global issues as the main theme and peace issues as a sub-topic.

The level of the classes varied from intermediate EFL at a junior high in Israel to upper-intermediate/advanced in Italy, intermediate in the EFL class in Japan and advanced in the ESL class in the U.S. Three of the four classes were mixed skill (focusing on listening, speaking, reading, and writing) with only the ESL class focusing on one skill, reading.

In Table 4.3, a total of six categories of materials and six categories of activities are included. These categories of materials and activities were selected from the first seven Teacher Surveys that were returned to the researcher (in order to create closed questions on the EFL I and ESL Surveys). Those materials that were mentioned most frequently on the first seven Teacher Surveys include: articles from human rights, environmental, development organizations; films/ videos; literature; newspaper articles; songs; and textbooks. The EFL classes in Italy and Japan used articles from human rights, environmental, and development organizations. All three 
EFL classes used films/ videos and newspaper articles. The EFL classes in Israel and Italy reported using literature. Only the EFL teacher in Israel used songs in her class. The EFL class in Japan and the ESL class used textbooks. Making Peace (1995), an ESL textbook with a peace education focus, was used by the ESL class.

The most commonly mentioned activities from the first seven Teacher Surveys include: debates; group discussions; guest lectures; research projects; role plays; and watching movies. Subjects in all four classes took part in group discussions. The class that used the greatest number of activities was the EFL class in Italy, which used all six activities. EFL students in Israel took part in debates as well as group discussions. In Japan subjects took part in group discussions, role plays, and watched movies. The ESL class used only one of the six categories of activities, group discussions.

\section{$\underline{\text { Response Rate }}$}

Three EFL and one ESL class participated in the Student Survey. The response rate for each of the classes is listed below. The first number listed indicates the total number of subjects that completed the survey. The second number represents the total number of students taking the respective class.

The teacher of the EFL class in Israel explained in an e-mail message to the researcher that the 25 students who received a copy of the Student Survey had studied peace issues at the beginning of the previous school year, a year and a half prior; 
therefore, the students' responses "might be a little vague".

The class with the lowest response rate was the EFL class in Italy. It is possible that the low response rate was due to the fact that the subjects received the Student Survey on the last day of the semester, together with their final exam and the evaluation for that course.

On the day that the EFL II Survey was group administered by the teacher in Japan, three students were absent from class. This class had the highest response rate.

In the ESL class in Oregon, the researcher group administered first the Card Sort (see Appendix C) and then the Student Survey. On that day two students were absent. Eight subjects participated in the Card Sort, due to one student arriving late; and nine participated in the Student Survey.

Israel

$18 / 25---72 \%$

Italy $\quad 12 / 62---19 \%$

Japan $\quad 31 / 34---91 \%$

Oregon, U.S. $\quad 9 / 12---75 \%$

\section{$\underline{\text { Results of Survey Items Measuring Interest and Comfort }}$}

Items measuring interest in and comfort with peace issues at the beginning and end of the term/ semester on the EFL I Survey differed from the items on the EFL II and ESL Surveys. The EFL classes in Italy and Israel completed the same version of the EFL survey. The survey items completed by the subjects in the EFL class in Japan 
were identical to the items completed by the ESL class in Oregon, United States. Because of there being two different ways in which interest and comfort were measured, the subjects answering the identical survey items are grouped together below.

\section{Interest and Comfort of Subjects in Israel and Italy}

The EFL classes in Israel and Italy completed Version I of the EFL Survey; therefore, these two classes are grouped together. A total of 18 subjects in the EFL class in Israel and 12 in Italy responded to survey items 7 and 8 . These closed questions elicit the subjects' feelings about discussing peace issues at the beginning of the term/ semester (item 7) and at the end of the term/ semester (item 8). Respondents could choose from the following categories to describe their feelings: interested, uninterested, comfortable, uncomfortable. An option was also given to write in another word under "other feelings."

When these questions were designed, it was predicted that responses would yield data on the subjects' interest/ disinterest in peace issues as well as yielding data on the subjects' comfort/ discomfort with peace issues. From the EFL class in Israel, all respondents checked either "interested" or "uninterested" on item 7; however, four subjects checked neither "comfortable" nor "uncomfortable." On item 8, four subjects checked neither "interested" nor "uninterested" and three subjects checked neither "comfortable" nor "uncomfortable." From the EFL class in Italy, one subject 
checked neither "interested" nor "uninterested" on item 7. Only one subject in this class used the words "comfortable" or "uncomfortable" to describe how he/she felt about discussing peace issues at the beginning of the term. Likewise, on item 8 , only one subject checked neither "interested" nor "uninterested," yet nine out of twelve EFL subjects in Italy checked neither "comfortable" nor "uncomfortable." Most of the surveys completed by subjects in the class in Israel yielded data on interest/ disinterest in peace issues as well as comfort/ discomfort with peace issues at the beginning and end of the term/ semester. Surveys completed by the class in Italy yielded data on interest/ disinterest in peace issues; however, virtually no data was obtained on this group of subjects' comfort/ discomfort with peace issues. For this reason, items 7 and 8 were revised on Version II of the EFL survey.

Figure 4.1 illustrates the responses of the EFL class in Israel to items 7 and 8 on the Student Survey. Responses to discussing peace issues at the beginning of the term/ semester are shown on the left side of Figure 4.1. Responses to discussing peace issues at the end of the term/ semester are shown on the right side of the graph. Ninety-four percent of the subjects, responding to item 7 on the survey, indicated that they were interested in discussing peace issues at the beginning of the term; and $6 \%$ indicated that they were uninterested. On item 8 of the survey, $72 \%$ indicated that they were interested in discussing peace issues at the end of the term and 5\% indicated that they were uninterested. Sixty-one percent of the respondents indicated that they were comfortable and $17 \%$ indicated that they were uncomfortable at the beginning of the 
FIGURE 4.1

percent INTEREST \& COMFORT OF SUBJECTS IN ISRAEL

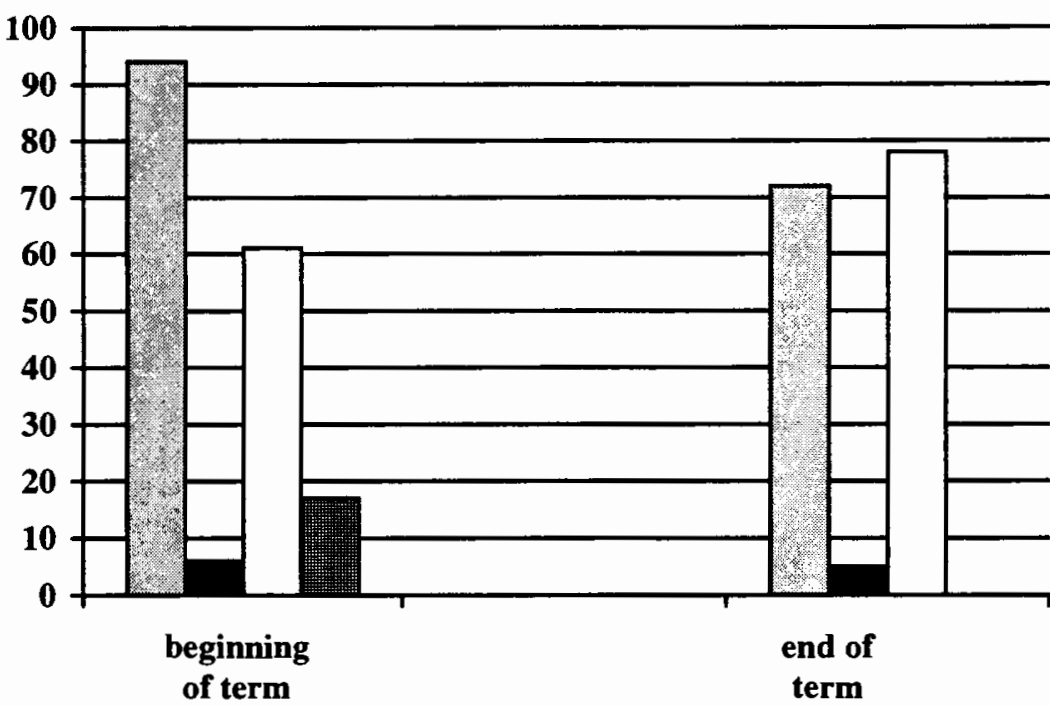

\begin{tabular}{|l|}
\hline interested \\
uninterested \\
$\square$ comfortable \\
uncomfortable
\end{tabular}

percent

FIGURE 4.2

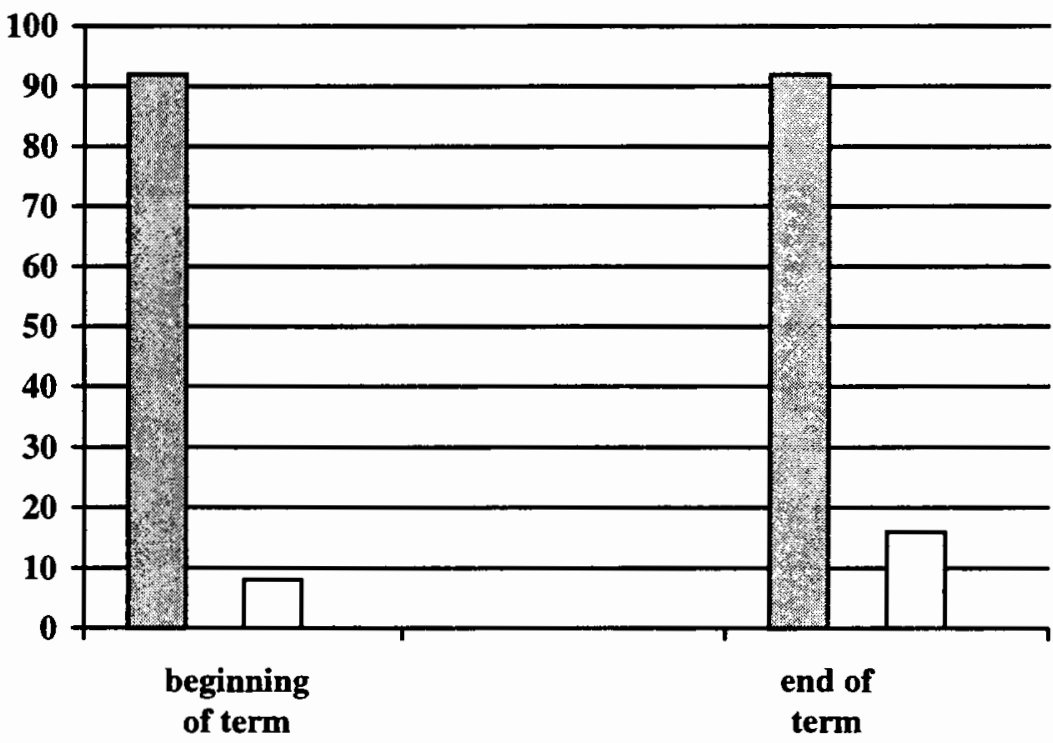

\begin{tabular}{|l|}
\hline interested \\
uninterested \\
$\square$ comfortable \\
uncomfortable \\
\hline
\end{tabular}


term/ semester. Seventy-eight percent indicated that they were comfortable discussing peace issues at the end of the term and $0 \%$ indicated a discomfort with discussing peace issues.

Figure 4.2 illustrates the results from the EFL class in Italy. As in Figure 4.1, subjects' feelings at the beginning of the semester are indicated on the right-hand side of the bar graph. Subjects' feelings about discussing peace issues at the end of the semester are shown on the left-hand side of the bar graph. Ninety-two percent of the respondents described their feelings about discussing peace issues at the beginning of the semester as "interested," $8 \%$ selected the word "comfortable" and $0 \%$ indicated a disinterest or discomfort. On item 8, $92 \%$ indicated that they were "interested" and $16 \%$ indicated that they "comfortable" discussing peace issues at the end of the semester. Zero percent selected the words "uninterested" or "uncomfortable" to describe how they felt about discussing peace issues at the end of the semester.

Written Comments. On survey items 7 and 8 , subjects were asked to explain their answers. Included below are all of the written comments from these survey items for subjects in the EFL classes in Israel and Italy.

\section{EFL class in Israel}

- [Interested \& comfortable] "I feel good because is interested."

- [Interested \& comfortable] "I was afraid, angry."/ "Better. Because I talked about things that bothered me and makes me upset."

- [Interested \& comfortable] "The peace was the important thing of my life." 
- [Interested] Other feeling: "I was afraid." (Two respondents wrote this comment.)

\section{EFL class in Italy}

- [Interested] “'Cause Peace is one of my interests (with art, music and Tolerance)"

- [Interested] "I never had the opportunity to study them so I was very interested."

- [Interested] "Because they are important for the society on which I live."

- [Interested] "Peace and liberty are the values I most believe in."

\section{Interest and Comfort of Subjects in Japan and Oregon, United States}

On the EFL II and ESL Surveys, the four items that measure subjects' interest in and comfort with peace issues at the beginning and end of the term/ semester are identical; therefore, the results from these two surveys are grouped together. A total of 31 respondents from the EFL class in Japan and 9 respondents from the ESL class in Oregon, U.S. completed surveys. Four questions, all 5-point Likert scales, were used to measure subjects' interest in and comfort with peace issues. The labels used are "very interested"/ "very uninterested" and "very comfortable"/ "very uncomfortable." On these 5-point Likert scales there is no neutral point. In the middle is the label "somewhat interested" and "somewhat comfortable." On the first two items that elicit 
subjects' feelings at the beginning of the term/ semester, the positive labels appear on the left-hand side. On the second two items, measuring feelings at the end of the term, the negative labels appear on the left-hand side. Alternating the labels as such was done in order to avoid influencing the subjects' responses. If a subject believes that the researcher predicts a particular response, the subject may be influenced to answer in that way, rather than selecting the item that most accurately reflects how the respondent feels. A disadvantage of alternating the position of the positive and negative labels on Likert-type items includes an increase in the likelihood that subjects may assume that labels of the same value are located on the same side throughout the survey; thus, the respondents may select labels of the opposite meaning from what they had intended to indicate. This is especially problematic when the survey participants are non-native English speakers and when time for filling out the survey is limited. This issue is discussed under limitations in Chapter V.

On the EFL II and ESL Surveys, interest and comfort are measured separately. On the EFL I Survey, interest at the beginning and end of the term/ semester is measured by items 8 and 10, respectively. Comfort is measured by items 7 (beginning of the term) and 9 (end of the term).

On the ESL Survey, interest at the beginning and end of the term/ semester is measured by items 10 and 12, respectively. Comfort is measured by items 9 (beginning of the term/ semester) and 11 (end of the term/ semester).

Interest of Subjects in Japan. Figure 4.3 illustrates the results from items 8 and 
percent

FIGURE 4.3 INTEREST OF SUBJECTS IN JAPAN

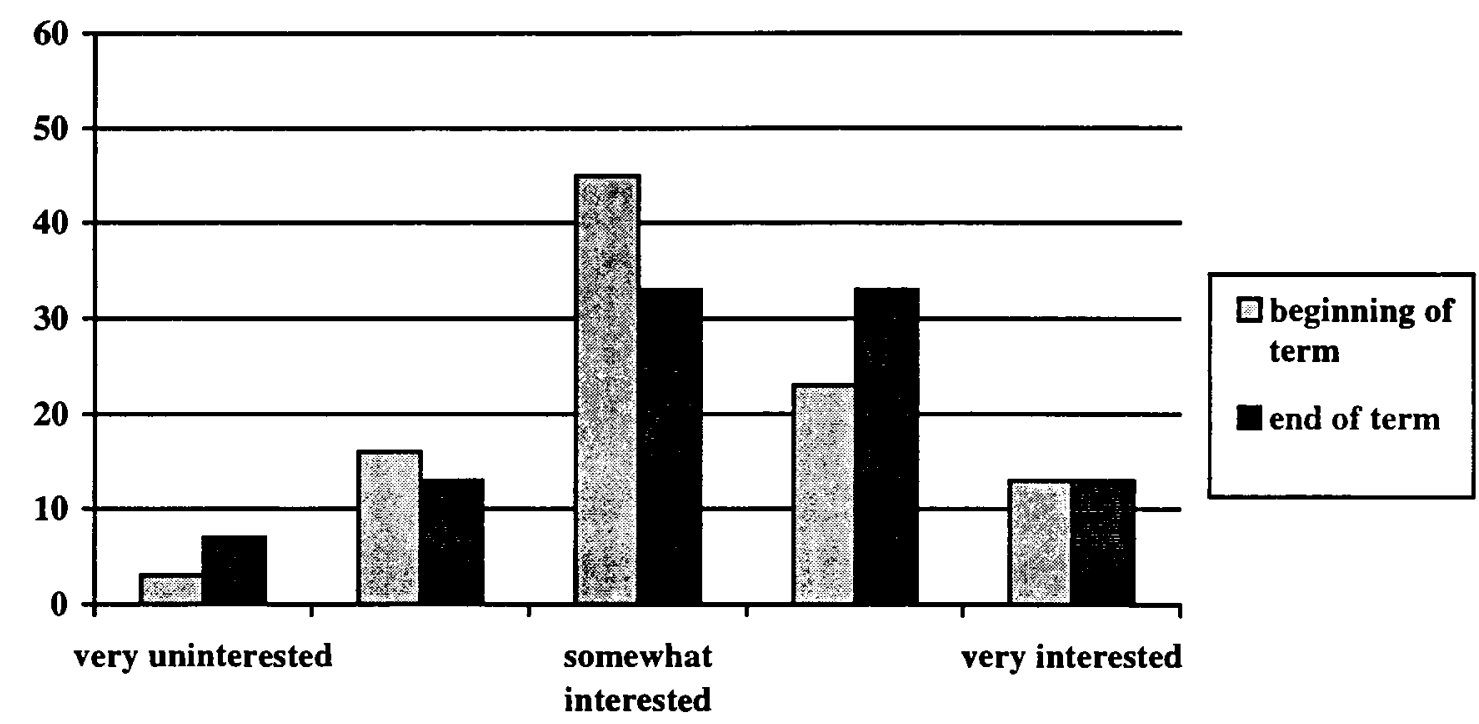

percent

FIGURE 4.4 INTEREST OF SUBJECTS IN U.S.

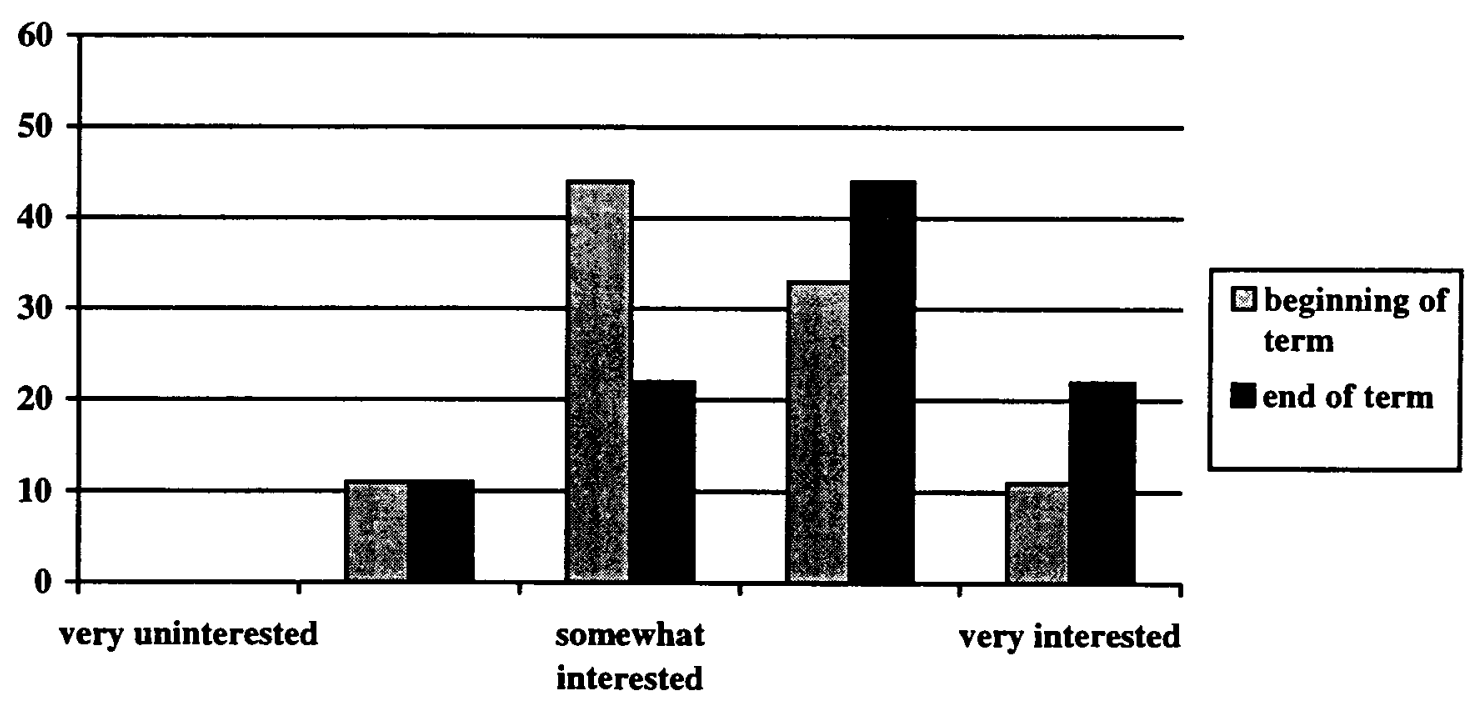


10 on Version II of the EFL Survey. Forty-five percent of the subjects indicated that they were "somewhat interested" at the beginning of the term, $23 \%$ "interested," $16 \%$ "not interested," $13 \%$ "very interested," 3\% "very uninterested." On the question measuring the interest of subjects at the end of the term/ semester, the percentage of "interested" subjects increased to $33 \%$, "somewhat interested" decreased to $33 \%$, "very interested" stayed the same at $13 \%$, "not interested" decreased to $13 \%$, and "very uninterested" increased to $7 \%$.

Interest of Subjects in Oregon, United States. In Figure 4.4, the results from items 10 and 12 on the ESL survey are shown. Forty-four percent of the subjects indicated that they were "somewhat interested" at the beginning of the term, $33 \%$ "interested," $11 \%$ "very interested," "not interested" also $11 \%$, and $0 \%$ "very uninterested." Responses to item 12 indicate an increase in interest, with $44 \%$ "interested," 22\% “very interested," $22 \%$ "interested," $11 \%$ "not interested" and 0\% "very uninterested."

Written Comments. Survey items 8 and 10 on the EFL II Survey and items 10 and 12 on the ESL Survey ask subjects to explain their answers. Included below are all of the written comments from these survey items for subjects in the EFL class in Japan and the ESL class in Oregon, United States. Preceding the written comments, given in order of most positive to least positive response, is the answer that the subject checked, indicated in brackets "[ ]". 


\section{EFL class in Japan}

- [Interested] "I'm interested in black people."

- [Not interested] "It's irritated me."

- [Very uninterested] "I don't read newspaper."

\section{ESL class in Oregon, United States}

- [Very interested] "When I have more knowledge about peace, I think I would like to pay more attention to Peace."

- [Very interested] "We know how to treat the peace problem in our mother country, but don't know how it is treated in a textbook in the U.S.A. I felt it favorable, because there are many essays [in Making Peace] which are treated impartially."

- [Interested] "I have already interested to live in peace."

- [Interested] "Because it's time right after talking about so many kinds of this issues."

- [Interested] "Of course it is an interesting topic, especially because all the people in the world are involve in it, but as I said before, sometimes some articles [in Making Peace] were unrealistic."

- [Somewhat interested] "Difficult to read \& understand!"

- [Somewhat interested] "I'm not interested always, but if I hear something about this topic, I'm interested in thinking or discussing it." 
percent

FIGURE 4.5 COMFORT OF SUBJECTS IN JAPAN

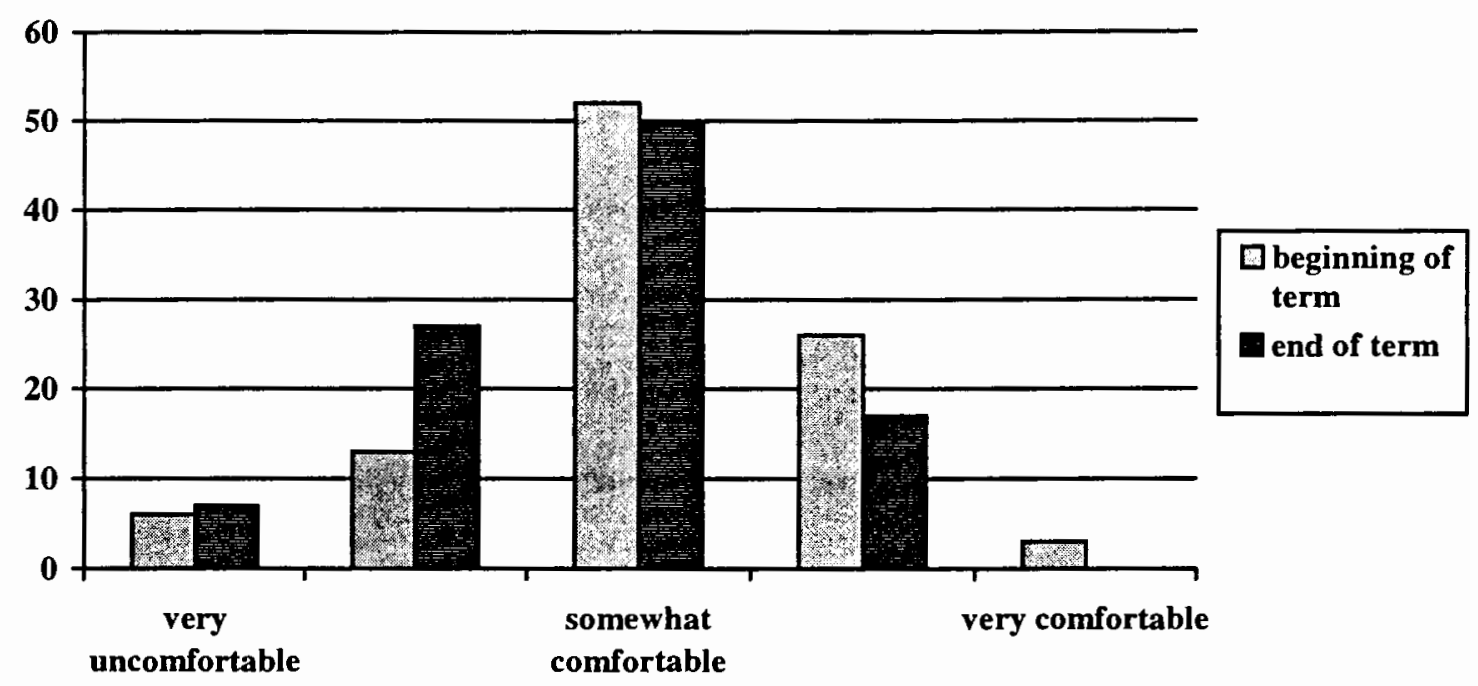

percent

FIGURE 4.6 COMFORT OF SUBJECTS IN U.S.

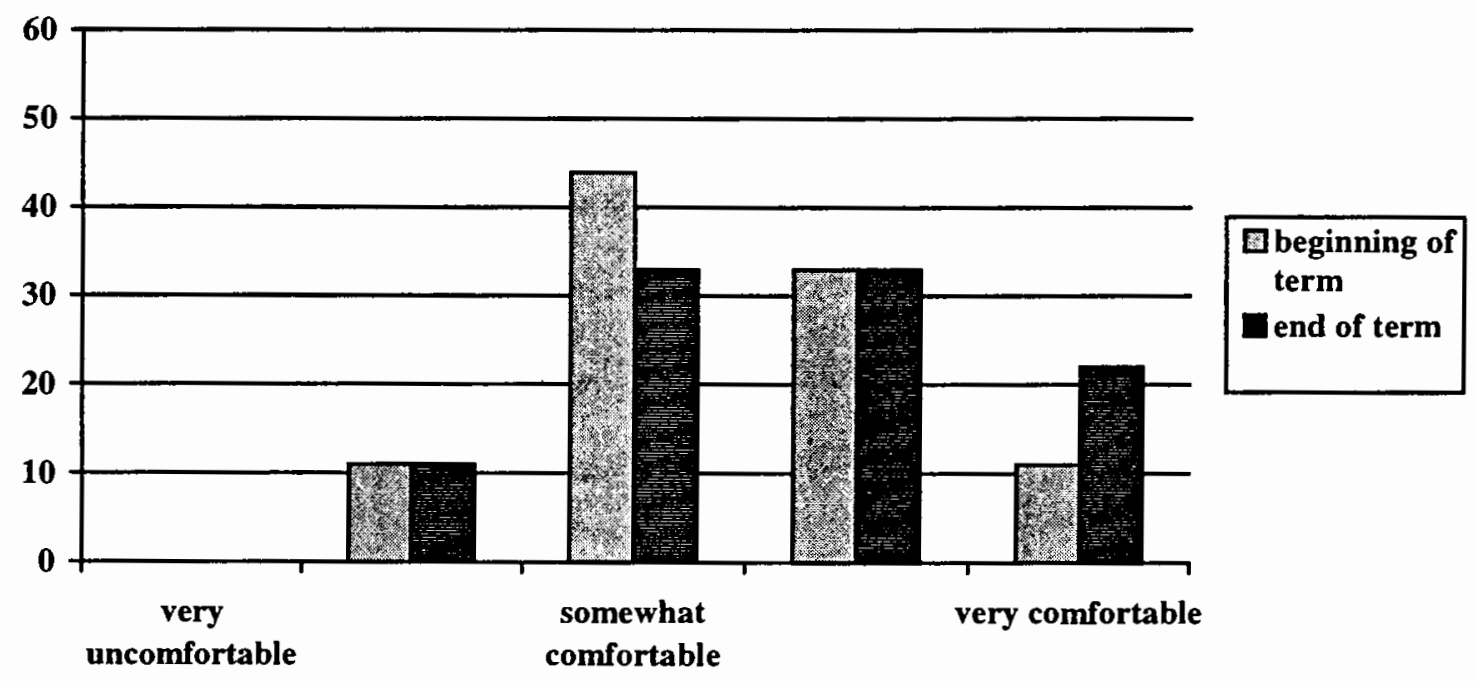


- [Very uninterested*] "I want to see some essays further."

*All of this subjects' written comments throughout the survey were positive. It is possible the subject assumed that all of the positive labels were located on one side and all of the negatives labels on the opposite side. In questions 9 and 11, the positive terms were on the left-hand side; in questions 10 and 12 the negative terms were on the left-hand side. This answer was from number 12 .

Comfort of Subjects in Japan. Figure 4.5 illustrates the results from items 7 and 9 on Version II of the EFL Survey. Fifty-two percent of the subjects indicated that they were "somewhat comfortable" at the beginning of the semester, $26 \%$ "comfortable," $13 \%$ "not comfortable," 6\% "very uncomfortable," 3\% "very comfortable." Responses to item 9 indicate that the level of comfort decreased at the end of the semester; $50 \%$ indicated that they were "somewhat comfortable," $27 \%$ were"not comfortable," $17 \%$ indicated that they were "comfortable," $7 \%$ reported feeling "very uncomfortable," and $0 \%$ were "very comfortable."

Comfort of Subjects in Oregon, United States. In Figure 4.6, the results from items 9 and 11 on the ESL Survey are shown. Forty-four percent of the subjects indicated that they were "somewhat comfortable" at the beginning of the term, $33 \%$ “comfortable," $11 \%$ "very comfortable," "not comfortable" also $11 \%$, and $0 \%$ "very uncomfortable." Responses to item 11 indicate an increase in comfort at the end of the term, with $33 \%$ indicating that they felt "comfortable," another 33\% reported feeling 
"somewhat comfortable." Twenty-two percent indicated that they felt "very comfortable," $11 \%$ were "not comfortable" and $0 \%$ were "very uncomfortable."

Written Comments. Items 7 and 9 on Version II of the EFL Survey and items 9 and 11 on the ESL Survey ask subjects to explain their answers. All of the written comments from these survey items for subjects in the EFL class in Japan and the ESL class in Oregon, United States are included below. Preceding the written comments, given in order of most positive to least positive response, is the answer that the subject checked, indicated in brackets "[ ]".

\section{EFL class in Japan}

- [Somewhat comfortable] "It is difficult"

- [Somewhat comfortable] "It's boring." (Same respondent as above.)

- [Somewhat comfortable] "It's very important to the world."

- [Not comfortable] "Difficult."

- [Not comfortable] “Not excite.” (Same respondent as above.)

- [Not comfortable] "I think I live in peace, so."

- [Not comfortable] "It's not reality for us."

- [Not comfortable] "I can understand only in my brain but I can't do anything." (Same respondent as above.)

- [Very uncomfortable] "People around me always speak Japanese."

- [Very uncomfortable] “ Because. They did not try!” 


\section{ESL class in Oregon, United States}

- [Very comfortable] "I really like those Topics because in this way I can hear others opinion and increase my knowledge."

- [Very comfortable] "We are usually apt to think that this kind of issues have no contact with us except war. To start with the first step of peace is very meaningful to me."

- [Comfortable] “Because, I can listen to another countries' people opinion. Also, I can know another countries' problem. It's interesting."

- [Comfortable] "It was o.k. but sometimes I felt it's too much. It is good to be concerned about this issue, however, it seemed too ideal sometimes which made discussion boring."

- [Comfortable] "It is the simple thing that we usually talk about."

- [Comfortable] "Same as at the beginning of the class, but I think I have more knowledge about peace and how to live with peace more." (Same respondent as above.)

- [Somewhat comfortable] "Some material are difficult to understand."

- [Somewhat comfortable] "This issue is closer to mental and psychological and more abstract. It's kind of difficult to understand completely what author talk about."

- [Somewhat comfortable] "I have not cared about the topic so much because for me this is one of the English class." 
- [Somewhat comfortable] "I don't dislike talking about this topic, but l don't like so much, either." (Same respondent as above.)

- [Not comfortable] "Because Those Topics were very hard for me at first, but after awhile I started to like them."

- [Very uncomfortable*] "There are many students who came from different countries, so it is very important to discuss the same theme."

*This subject, as discussed above, apparently assumed that all of the positive values were located on the same side of all Likert scales.

\section{Assessment of Materials}

On the EFL I Survey, three open questions, items 15,16 and 17, ask subjects to list the materials that were interesting, those that were uninteresting, and those materials which helped subjects to improve their English. There is no question on the EFL I Survey that asks subjects to list the materials that they found least useful.

On the EFL II Survey, subjects ranked the materials from "most interesting" to "least interesting" on item 16. The same question appears on the ESL Survey under item number 18. On item 17 of the EFL II Survey and 19 of the ESL Survey, subjects rank the materials from "most useful (for improving my English)" to "least useful."

Table 4.4 presents the results of EFL I, EFL II, and ESL Survey items measuring what subjects thought about the materials used in their respective classes with regard to interest and usefulness for improving one's English. The percentages 
for the responses to the open questions on the EFL I Survey were calculated by dividing the number of subjects who indicated a particular material as "interesting," "uninteresting," or "useful" by the total number of participants who completed the respective survey item. For responses to the rankings from the EFL II and ESL Surveys, percentages were calculated by dividing the number of subjects who ranked a

TABLE 4.4 STUDENTS' ASSESSMENT OF MATERIALS

\begin{tabular}{|c|c|c|c|c|c|}
\hline \multirow{2}{*}{$\begin{array}{c}\text { EFL class } \\
\text { in Israel }\end{array}$} & materials & interesting & uninteresting & useful & $\begin{array}{c}\text { not } \\
\text { useful }\end{array}$ \\
\hline & $\begin{array}{l}\text { literature } \\
\text { newspapers } \\
\text { songs }\end{array}$ & $\begin{array}{l}11 \% \\
11 \% \\
39 \%\end{array}$ & $\begin{array}{l}17 \% \\
0 \% \\
6 \%\end{array}$ & $\begin{array}{l}22 \% \\
33 \% \\
22 \% \\
\end{array}$ & $\begin{array}{c}{ }^{*} \text { not } \\
\text { measured } \\
\text { on EFL I }\end{array}$ \\
\hline \multirow[b]{2}{*}{$\begin{array}{l}\text { EFL class } \\
\text { in Italy }\end{array}$} & materials & interesting & uninteresting & useful & $\begin{array}{c}\text { not } \\
\text { useful }\end{array}$ \\
\hline & $\begin{array}{l}\text { articles } \\
\text { films/ videos } \\
\text { literature } \\
\text { newspapers }\end{array}$ & $\begin{array}{c}33 \% \\
17 \% \\
0 \% \\
25 \%\end{array}$ & $\begin{array}{l}0 \% \\
0 \% \\
0 \% \\
0 \%\end{array}$ & \begin{tabular}{|l}
$8 \%$ \\
$8 \%$ \\
$8 \%$ \\
$25 \%$ \\
\end{tabular} & $\begin{array}{c}{ }^{*} \text { not } \\
\text { measured } \\
\text { on EFL I }\end{array}$ \\
\hline \multirow{2}{*}{$\begin{array}{l}\text { EFL class } \\
\text { in Japan }\end{array}$} & materials & $\begin{array}{c}\text { most } \\
\text { interesting }\end{array}$ & $\begin{array}{c}\text { least } \\
\text { interesting }\end{array}$ & $\begin{array}{l}\text { most } \\
\text { useful }\end{array}$ & $\begin{array}{c}\text { least } \\
\text { useful }\end{array}$ \\
\hline & $\begin{array}{l}\text { articles } \\
\text { films / videos } \\
\text { newspapers } \\
\text { textbook }\end{array}$ & $\begin{array}{l}23 \% \\
39 \% \\
13 \% \\
10 \%\end{array}$ & $\begin{array}{l}19 \% \\
23 \% \\
23 \% \\
23 \%\end{array}$ & $\begin{array}{l}35 \% \\
39 \% \\
26 \% \\
26 \%\end{array}$ & $\begin{array}{c}10 \% \\
10 \% \\
6 \% \\
13 \%\end{array}$ \\
\hline \multirow{2}{*}{$\begin{array}{c}\text { ESL class } \\
\text { in Oregon, } \\
\text { U. S. }\end{array}$} & materials & $\begin{array}{c}\text { most } \\
\text { interesting }\end{array}$ & $\begin{array}{c}\text { least } \\
\text { interesting }\end{array}$ & $\begin{array}{l}\text { most } \\
\text { useful }\end{array}$ & $\begin{array}{c}\text { least } \\
\text { useful }\end{array}$ \\
\hline & textbook & $56 \%$ & $3 \%$ & $89 \%$ & $0 \%$ \\
\hline
\end{tabular}

*Note: There is no question on the EFL I Survey which asks subjects to list the materials that they found least useful. 
material "most interesting"/ "least interesting" or "most useful"/ "least useful" by the total number of participants who completed the respective survey item. In order that the four classes could be compared, only the extremes of the rankings were calculated.

To the open question on the EFL I Survey "Which materials were interesting," $39 \%$ of the respondents in Israel indicated songs, $33 \%$ of the respondents in Italy indicated articles from development, human rights, environmental, and peace organizations. To the question "Which materials helped you to improve your English," $33 \%$ of the respondents in Israel and $25 \%$ of the respondents in Italy listed newspaper articles.

On the rankings of the EFL II and ESL Surveys, 39\% of the respondents in Japan indicated that films/ videos were the "most interesting" and "most useful" material. Only one type of material (from the six categories) was used in the ESL class. Fifty-six percent of the respondents to this survey item ranked the textbook used in their class as "most interesting" and 89\% ranked it as "most useful."

\section{Assessment of Activities}

EFL II Survey respondents filled out 5-point Likert-type items for each activity on item number 13 , with the activities listed from a-f. The following bipolar anchors appear on the Likert-type items: "liked a lot"/ "did not like at all;" and "very useful (for improving my English)"/ "not useful at all."

On Version II of the EFL Survey, subjects ranked the activities from "liked most" 
to "liked least" on item 14. The same question appears on the ESL survey under item number 16. Subjects in the EFL class in Japan ranked the activities from "most useful (for improving my English)" to "least useful" on item 15. The ESL subjects in Oregon, United States ranked the usefulness of the activities on item 17.

Table 4.5 presents the results of EFL I, EFL II, and ESL Survey items measuring what subjects thought about the activities used in their respective classes.

TABLE 4.5 STUDENTS' ASSESSMENT OF ACTIVITIES

\begin{tabular}{|c|c|c|c|c|c|}
\hline \multirow{2}{*}{$\begin{array}{c}\text { EFL class } \\
\text { in Israel }\end{array}$} & activities & $\begin{array}{l}\text { liked } \\
\text { a lot }\end{array}$ & $\begin{array}{l}\text { did not } \\
\text { like at all }\end{array}$ & $\begin{array}{l}\text { very } \\
\text { useful }\end{array}$ & $\begin{array}{l}\text { not useful } \\
\text { at all }\end{array}$ \\
\hline & $\begin{array}{l}\text { debates } \\
\text { group discussions }\end{array}$ & $\begin{array}{l}72 \% \\
89 \% \\
8\end{array}$ & $\begin{array}{l}0 \% \\
0 \%\end{array}$ & $\begin{array}{l}67 \% \\
-72 \% \\
\end{array}$ & $\begin{array}{l}6 \% \\
0 \% \\
\end{array}$ \\
\hline \multirow[b]{2}{*}{$\begin{array}{l}\text { EFL class } \\
\text { in Italy }\end{array}$} & activities & $\begin{array}{l}\text { liked } \\
\text { a lot }\end{array}$ & $\begin{array}{l}\text { did not } \\
\text { like at all }\end{array}$ & $\begin{array}{l}\text { very } \\
\text { useful }\end{array}$ & $\begin{array}{c}\text { not useful } \\
\text { at all }\end{array}$ \\
\hline & $\begin{array}{l}\text { debates } \\
\text { group discuissions } \\
\text { guest lectures } \\
\text { research projects } \\
\text { role plays } \\
\text { watching movies }\end{array}$ & $\begin{array}{c}67 \% \\
75 \% \\
58 \% \\
58 \% \\
58 \% \\
17 \%\end{array}$ & $\begin{array}{l}8 \% \\
0 \% \\
0 \% \\
0 \% \\
8 \% \\
0 \%\end{array}$ & $\begin{array}{c}58 \% \\
75 \% \\
67 \% \\
67 \% \\
50 \% \\
25 \%\end{array}$ & $\begin{array}{l}0 \% \\
0 \% \\
0 \% \\
0 \% \\
0 \% \\
0 \%\end{array}$ \\
\hline \multirow{2}{*}{$\begin{array}{c}\text { EFL class } \\
\text { in Japan }\end{array}$} & activities & $\begin{array}{l}\text { liked } \\
\text { most }\end{array}$ & $\begin{array}{l}\text { liked } \\
\text { least }\end{array}$ & $\begin{array}{l}\text { most } \\
\text { useful }\end{array}$ & $\begin{array}{l}\text { least } \\
\text { useful }\end{array}$ \\
\hline & $\begin{array}{l}\text { group ciscussions } \\
\text { role plays } \\
\text { watohing movies }\end{array}$ & $\begin{array}{l}16 \% \\
10 \% \\
39 \% \\
\end{array}$ & $\begin{array}{l}35 \% \\
26 \% \\
16 \%\end{array}$ & $\begin{array}{l}45 \% \\
23 \% \\
32 \%\end{array}$ & $\begin{array}{c}13 \% \\
6 \% \\
13 \% \\
\end{array}$ \\
\hline \multirow{2}{*}{$\begin{array}{l}\text { ESL class } \\
\text { in Oregon, } \\
\text { U.S. }\end{array}$} & activities & $\begin{array}{l}\text { liked } \\
\text { most }\end{array}$ & $\begin{array}{l}\text { liked } \\
\text { least }\end{array}$ & $\begin{array}{l}\text { most } \\
\text { useful }\end{array}$ & $\begin{array}{l}\text { least } \\
\text { useful }\end{array}$ \\
\hline & group discuissions & $33 \%$ & $3 \%$ & $33 \%$ & $0 \%$ \\
\hline
\end{tabular}


The percentages for the Likert-type items on the EFL I Survey were calculated by dividing the number of subjects who rated an activity "liked a lot"/ "did not like at all" or "very useful"/ "not useful at all" (only the extremes are calculated) by the total number of participants who completed the respective survey item. For responses to the rankings of the EFL II and ESL Surveys, percentages were calculated by dividing the number of subjects who ranked an activity "liked most"/ "liked least" or "most useful"/ "least useful" (only the extremes of the rankings are calculated) by the total number of participants who completed the respective survey item.

Of the activities assessed by the EFL I Survey respondents, group discussions were rated highest. In the EFL class in Israel, 89\% selected "liked a lot" and 72\% indicated that group discussions were "very useful." In the EFL class in Italy, 75\% selected "liked a lot" and again 75\% indicated that group discussions were "very useful."

Thirty-nine percent of the respondents in Japan indicated that watching movies was the activity that they "liked most." Group discussions was selected as the "most useful" activity by $45 \%$ of the EFL class in Japan. Subjects in the ESL class ranked only one activity, group discussions. Thirty-three percent indicated that group discussions was the activity that they "liked most" and 33\% reported that it was "most useful" for improving their English. 
Summary

This chapter has presented the results from thirteen Teacher Surveys and seventy Student Surveys. Data presented from the Teacher Surveys focused on ESLEFL teachers' definitions of peace education, a rationale for teaching peace education, and how peace education is taught in ESL/EFL classes. In the final section presenting Teacher Survey data, four ESL/EFL teachers, whose classes participated in the Student Survey, commented on how their students responded. Student Survey data were presented in five sections: 1) background;2) response rate; 3 ) results of the survey items measuring interest and comfort; 4) assessment of materials; and 5) assessment of activities. In the following chapter, the findings from the Teacher and Student Surveys will be discussed. Chapter V will also address limitations of the study, suggestions for further research, and implications for the field of TESOL. 


\section{CHAPTER V}

\section{DISCUSSION \& CONCLUSIONS}

This chapter discusses the findings from thirteen Teacher Surveys and seventy

Student Surveys. Also addressed are the limitations of the study, suggestions for further research, and implications for the field of TESOL.

\section{Discussion of the Findings}

Teacher and Student Survey data which address the seven research questions for this study are discussed below. Three research questions focused on teacher subjects and four on the student subjects.

\section{Teacher Survey}

The criteria for selecting the teacher subjects for this study were that they teach or plan to teach peace issues as the central theme or a sub-topic in an ESL/EFL class. All teachers meeting these criteria were included in the study. Other variables such as the setting, the level of the learners, and the focus of the class could not be controlled. Qualitative survey data were collected from seven ESL and six EFL teachers 
using an eight item questionnaire. Four of the eight open questions answered the research questions. Survey item one corresponded to the first research question and survey item two with the second research question. Items three and four of the Teacher Survey focused on the third research question.

\section{How do ESL/EFL teachers define peace education?}

Based on the review of the literature, it was predicted that ESL/EFL teachers' definitions of peace education would vary. Peace education is a newly developing field; therefore, disagreement over the terminology still exists. In addition, as noted by Okamoto (1993), there are a variety of approaches to teaching peace education, with each approach bearing a different label reflecting the focus. Reardon (1988) explains that peace education must be under all circumstances value based and deal with the core issue of peace education, namely violence.

Responses on the Teacher Survey to the open question "How do you define Peace Education" confirmed that variation among ESL/EFL teachers' definitions of peace education does exist. Definitions of the participants who seemed to have a theory base in peace education varied only slightly from one another. The greatest differences found were between the responses of educators who seemed to be familiar with the theory of peace education and those who were not. For ESLEFL teachers who identify themselves as peace educators, it is critically important to build a theory base in peace education. Without this foundation, there is the danger of teachers 
indoctrinating their students. As a minimum, all peace educators should familiarize themselves with the work of Reardon (1988).

Why have some ESL/EFL teachers decided to teach peace education in their classes?

As a rationale for teaching peace education in ESL/EFL classes, the most common response fell under the category "responsibility of the ESL/EFL teacher." A common thread that ran through all of the thirteen ESL/EFL teachers' responses to this survey item is a sense of concern, from a concern about improving relations among students in the ESLEFL class who are of different cultural backgrounds to a concern about the state of the planet. One of the two teachers whose comment was categorized under "peace education was not chosen," does not identify himself as a peace educator, yet he does express a concern for treating his students in a caring way. In a forward to his survey responses, this teacher commented, “...Peace is promoted by behavior much better than words. We make it a policy [at our English institute] to be especially hospitable to religions and cultures different from our own, taking Muslim holidays at least as seriously as Christian ones." The second teacher, who wrote that she had not chosen to teach peace education and does not identify herself as a peace educator, explained to the researcher in a conversation that she shares a lot of the values that peace educators hold.

It seems clear from the responses of the teachers who identified themselves as teaching peace education that their rationale for incorporating peace issues into the 
ESL/EFL class is connected to a concern for bringing about change in their students which may, in turn, contribute in some way toward the building of a more peaceful world. This change may constitute increasing students' awareness about peace issues; it may also include teaching students the skills of conflict resolution in addition to developing in students a concern for social justice and respect for oneself and all other living beings. Whether teachers make a conscious decision to promote peace in their class or not, as pointed out by one teacher above, peace is taught not only by words, but also by behavior. Birch (1992) explains that it is not just the teaching of peace concepts that constitutes peace education. ESL teachers who create an atmosphere of trust, cooperation, and respect in their classrooms are teaching peace.

\section{How do ESL/EFL teachers incorporate peace education into their classes?}

Each of the participating teachers incorporated peace education into the ESL/EFL class in a unique way. As discussed above, teachers' definitions of peace education varied; thus, it would be predicted that the teachers' approaches would also vary. The areas in which overlap among the twelve classes (one subject was planning on teaching peace education) was found included the use of authentic materials and engaging students in group discussions and debates.

Many of the classes used authentic materials. Those classes with a required textbook supplemented the curriculum by bringing in authentic materials and realia. There was considerable variation from class to class in the number and type of 
materials used. Some classes used one or two materials, while others included the use of six or more.

It is interesting to note that three of the respondents reported using materials from non-governmental organizations. Teachers using these materials offer ESLEFL students an opportunity to study about peace issues from an unbiased perspective, one that is not influenced by any one particular government. Reardon (1988) asserts that peace education, influenced by world order studies, is transnational. In order to look beyond national borders, it is essential to examine issues from many perspectives, taking into consideration points of view from a variety of systems and traditions.

All of the teachers mentioned group discussion as an activity used in their class. Many also had their students engage in debates. Several classes did presentations, role plays/ simulations and had guests give lectures in the class. Having students involved in activities which require cooperation, critical thinking, problem-posing and problem solving, and peaceful conflict resolution were among the most common types mentioned.

The results from the Teacher Surveys indicated that there are many ways in which peace education is defined, as well as many ways in which peace education can be taught, explicitly or implicitly. In general, the teacher subjects seemed to be aware of the charge made by some that peace education is a form of indoctrination. Two of the respondents addressed this issue directly. One EFL teacher wrote, "I don't believe in trying to indoctrinate students to one position...I think that there should be open 
dialogue with different perspectives presented and allowed. Students have to ultimately come to their own conclusions." An ESL teacher responding to the question "What worked/ what didn't work" answered, "It doesn't work to tell students what they should think."

\section{$\underline{\text { Student Survey }}$}

The qualitative and quantitative data from the EFL I, EFL I, and ESL Surveys are discussed with regard to four research questions.

Do any patterns emerge when examining the group of student subjects who show the greatest interest in peace issues?

In the EFL class in Israel, eleven subjects (out of eighteen) indicated that they were interested in peace issues at the beginning and end of the semester. No patterns were found with regard to age, gender, or country of residence. Patterns did seem to emerge in the area of time spent outside one's home country. Four of the subjects had lived outside Israel, one in Georgia and three in Russia. (The teacher of this class mentioned on the Teacher Survey that some of the students had immigrated from the former Soviet Union.) A total of seven subjects in this class indicated having lived in another country for three months or more. More than half of those respondents scored in the most interested range.

In the EFL class in Italy, ten subjects (out of twelve) indicated that they were 
interested in peace issues at the beginning and end of the semester. No patterns were found with regard to age or gender. As with the class in Israel, the pattern found among the respondents from the EFL class in Italy was in time spent living outside one's country. All of the subjects in this class (out of the total population) who had spent three months or more living in another country scored in the "most interest in peace issues" category.

Subjects who showed the greatest interest in the EFL class in Japan numbered nine (out of thirty-one). These subjects were identified by having selected "interested" and/or "very interested" at the beginning and end of the semester. With regard to age and gender no patterns were found. All nine of these subjects were residents of Japan. Seven subjects had not lived outside Japan for three months or more. Two out of the three subjects, in the class of thirty-one, who had spent time living in another country for three months or more scored in this category.

Subjects from the ESL class in the United States showing the greatest interest in peace issues included one male from Thailand and two females, from Iran and Japan. There were more female than male students in this class; therefore, no patterns could be determined with regard to gender. All of the students had been living in the United States for three months or more; as a result, this factor could not be considered when searching for patterns. The total number of participants in the ESL class was too low to determine whether or not patterns existed with regard to country of origin.

From this study, no conclusions can be drawn about how other groups of 
subjects may respond to studying peace issues; however, the results seem to indicate that an interest in peace issues may be found among students of a variety of backgrounds. Furthermore, students' responses to peace issues may depend mostly upon how effective the teacher is in drawing an explicit connection for the students between the goals of peace education and the goals of the ESL/EFL class.

Do any patterns emerge when examining the group of student subjects who show the least interest in peace issues?

"Least interested in peace issues" for respondents to the EFL I Survey was determined by a subject having selected "uninterested" at the beginning and end of the semester. None of the subjects in the EFL class in Israel checked "uninterested" at the beginning and end of the semester. (One subject selected "uninterested" at the beginning and "interested" at the end of the semester. Two subjects selected "interested" at the beginning of the semester and "uninterested" at the end of the semester.) None of the subjects in the EFL class in Italy selected "uninterested" at the beginning or end of the semester.

Respondents to the EFL I and ESL Surveys "least interested in peace issues" included subjects who had selected the answers "not interested" and/or "very uninterested" at the beginning and end of the semester. In the EFL class in Japan four subjects scored in the least interested category. No patterns were found with regard to age, gender, or country of residence. All four of the "least interested" participants in 
Japan had not lived outside their country for three months or more. None of the respondents from the ESL class in the United States scored in the least interested category.

Due to the fact that nearly all of the EFL participants in Japan (28 out of 31) had not spent time in another country, it cannot be determined whether or not a lack of time spent abroad is connected with a disinterest in peace issues. It is possible that the disinterest of these subjects may have been a result of the materials being too difficult or the subjects disliking an activity or finding an activity not useful.

Which materials do students find the most interesting and the most useful for improving their English?

To the open question on the EFL I Survey "Which materials were interesting," respondents in Israel indicated songs, the respondents in Italy indicated articles from development, human rights, environmental, and peace organizations. To the question "Which materials helped you to improve your English," the respondents in Israel and the respondents in Italy listed newspaper articles. Subjects in the classes in Israel and Italy selected newspaper articles as "useful" more frequently than any other material.

On the rankings of the EFL II and ESL Surveys, the respondents in Japan indicated that films/ videos were the "most interesting" and "most useful" material. Only one material (from the six categories) was used in the ESL class. Subjects in the ESL class used the textbook Making Peace which they seemed to find interesting and 
useful for improving their English.

Which activities do students like the most and find the most useful for improving their English?

In three out of the four participating classes, group discussions was the activity that students liked the most; the next highest scoring activity in two classes was debates. With regard to usefulness for improving one's English, group discussions scored highest in all four classes.

The results suggest that group discussions are an effective way for teachers to incorporate peace education into the ESL/EFL class. This type of activity allows students to develop active listening skills, an essential element of conflict resolution. In group discussions, students also have an opportunity to listen to the points of view of their peers as well as learning to express their own opinion. It is important for teachers to be prepared to deal with conflict which may arise due to differences of opinion on controversial issues. ESL/EFL teachers may prepare themselves by attending training sessions in conflict resolution as well as becoming knowledgeable about the cultural backgrounds of the individual students in the class.

\section{Limitations of the Study}

Limitations of the Teacher Survey included the data analysis. Using a key 
word analysis, responses to the first two open questions were categorized. By placing responses into categories, it is possible that some of the meaning may have been lost.

One aim of this study was to measure ESL/EFL students' interest in and comfort with peace issues. Problems with the survey design, together with the fact that follow up interviews could not be conducted (with participants from classes with peace issues as the central theme), were limiting factors. Cultural background and English language proficiency of the student subjects could be considered only to a limited extent when designing the instruments. Because of this, the face validity of Student Survey items is uncertain. Items on the EFL I Survey which were designed to measure both interest and comfort provided little or no information about subjects' comfort. Due to the fact that not all student survey participants completed the same version of the Student Survey, results from the classes in Israel and Italy could not be compared with the results of Japan and the United States.

\section{Suggestions for Further Research}

Gomes de Matos (1988) and Larson (1990) point out the need for further research to be done on ESL/EFL classes that incorporate peace education. Gomes de Matos (1988) asks, "How can peace-oriented courses be designed, field tested, and improved" (p. 16). Larson (1990) poses the following questions, "Are prospective ESOL teachers being prepared to teach in such programs [those that deal with peace 
issues], to design such programs? To what extent is global understanding or peace studies a focus in our programs of teacher education? Perhaps we could undertake a survey, carried out with the assistance of our [TESOL's] Teacher Education Interest Section" (p. 21).

Clearly with the interest in peace education growing, there is a need for more studies to be carried out. More needs to be learned about the preparedness of ESOL teachers to address peace issues in their classes. The researcher suggests that future teacher surveys include follow up interviews in order to add context to the teachers' responses. In addition, studies need to be carried out that will help ESOL educators learn about students' reactions to studying peace education in an ESL/EFL class.

This study provides a foundation upon which further Teacher and Student Surveys can be carried out. A final, revised copy of the instrument used in this study to collect student survey data appears in Appendix C. Changes were made to the EFL II and ESL Surveys (described in Appendix C) to create the Recommended Student Survey, designed for collecting student survey data in both ESL and EFL settings.

It is suggested that future surveys include questionnaires and follow up interviews with the subjects in order that unclear or incomplete survey items can be explained. In order to learn more about students' attitudes toward studying peace education in ESL/EFL classes, data from case studies may provide a more accurate picture than survey data. By visiting the classroom or videotaping classroom interaction the researcher may gain valuable information on how students feel through 
analysis of the behavior observed.

Implications for the Field of TESOL

For ESL/EFL educators interested in teaching peace education, this study provides a start for building a theory base. ESL/EFL teachers may have a greater understanding of what peace education is, how and why it is taught, as well as what the issues are in the debate over its appropriateness for the ESL/EFL class. The researcher suggests that TESOL programs offer courses to prepare ESL/EFL educators to teach peace education. These courses should be grounded in both a theory of peace education and second/foreign language teaching. Teachers should be able to take away from the class a repertoire of skills and methods for teaching peace, including an understanding of non-violent conflict resolution.

Student Survey responses in all four classes seemed to indicate that more subjects were interested in peace issues than uninterested. Among the students who expressed a disinterest in peace issues, the most common explanation given was that the material was too difficult. The researcher suggests that authentic materials be adapted for low level learners. These subjects' comments also point to the need for the development of more ESL/EFL materials on the theme of peace education, especially for low level learners. 
Conclusion

During the two years that the researcher worked on this study, she found that her own definition of peace education changed. At the beginning of the study, the researcher was unaware that peace education was based on a systems approach. The researcher now defines peace education as a field which is transnational and transdisciplinary, with a value orientation, valuing peace and opposing violence. Peace education brings into the classroom a dimension often void in many traditional classes (whether it be a language, history, or social studies class), namely an affective dimension. That is, in peace education classes the student becomes involved not only with her mind but also with her heart. As illustrated in Chapter 2 (p. 14), students take away from a peace education class such attitudes as self-respect, respect for others, ecological concern, open-mindedness, vision, and a commitment to justice. Whether or not these goals can be achieved is in part dependent upon the role that the teacher plays in the classroom. Brock-Utne (1985) points out the importance of consistency of values and a commitment to ending inequality of all kinds. Every decision that a teacher makes is in some way political and can have an impact on the students. Two areas of particular concern are the grading system and the characteristic hierarchical relationship between the teacher and the students.

Long before the researcher had ever heard about "peace education", she had wondered how it might be possible to bring into the language class a method of 
teaching which would encourage the development of more peaceful relations among all people and between humans and the environment. The teachers in this study have demonstrated how this is possible.

"Since wars begin in the minds of men, it is in the minds of men that the defenses of peace must be constructed"

(UNESCO Constitution) 


\section{REFERENCES}

Ashworth, M. (1990, February). TESOL peace education. TESOL Newsletter, p. 4.

Ashworth, M. (1991). Internationalism and our strenuous family. TESOL Quarterly, 25, (2), 231-243.

Baldwin, R. J. (1992, June/July). Humanistic teaching in the second-language classroom. TESOL Matters, 2 (3), 15.

Birch, B. (1992, June/July). ESL peaceteachers. TESOL Matters, 2 (3), 11.

Bjerstedt, Å. \& "preparedness for peace". (1994, February). The meaning of "peace education": Associations, emphases, and sub-categories. (Peace Education Reports No. 9). Malmö: Lund University, Department of Educational and Psychological Research. (Rep. No. ISSN: 1101-6426).

Bjerstedt, Å. \& "preparedness for peace". (1995, March). Controversies connected with peace education. What do they mean and how should they be dealt with?. (Peace Education Reports No. 15). Malmö: Lund University, Department of Education and Psychological Research. (Rep. No. ISSN: 1101-6426).

Brinton, D. M., Snow, M. A., \& Wesche, M. B. (1989). Content-based second language instruction. New York: Newbury House Publishers.

Brock-Utne, B. (1985). Educating for peace: A feminist perspective. New York: Pergamon Press.

Brooks, E. \& Fox, L. (1995). Making peace: A reading/ writing/ thinking text on global community. New York: St. Martin's Press.

Brown, H. D. (1991). TESOL at twenty-five: What are the issues? TESOL Quarterly, 25, (2), 245-260.

Busch, M. (1993). Using Likert scales in L2 research: A researcher comments. TESOL Quarterly, 27, (4), 733-736.

Cates, K. (1992). Global education, peace education and language teaching. TESL Reporter, 25 (1), 1-9. 
Cremin, P. (Ed.). (1993). Education for peace. Educational Studies Association of Ireland and the Irish Peace Institute.

Cummins, J. (1979). Linguistic interdependence and the educational development of bilingual children. Review of Educational Research, 49, 222-251.

Eggington, W. (1992/1993). On the sociopolitical nature of English language teaching. TESOL Matters, $\underline{2}(6), 4$.

Eggington, W. (1993). Preparing our students for choices: Response to Susan Francis Jones' "culture teaching or English teaching". TESOL Matters, $\underline{3}$ (3), 19.

Fine, L. (1990, February). Resolving conflict creatively: Peace education concepts in the ESL classroom. TESOL Newsletter, p. 19.

Fisher, R. \& Ury, W. (1981). Getting to yes: Negotiating agreement without giving in. New York: Penguin Books.

Fitzpatrick, K. (1994). The use of global issues in a university ESL classroom: The students' perspective. Unpublished thesis. Portland: Portland State University.

Fowler, Jr., F. J. (1993). Survey research methods. Newbury Park: Sage Publications.

Fox, L. (1990, April). Planethood: An ESL writing course on global community. TESOL Newsletter, 24 (2), 19.

Fox, L. (1992, February/March). Doing peace education: Getting started. TESOL Matters, 2 (1), 7.

Freudenstein, R. (1993). Integrating peace into the foreign language curriculum. In A. Raasch (Ed.), Language teaching in a world without peace. Saarbrücken: Druckerei der Universität des Saarlandes.

Galtung, J. (1985). Twenty-five years of peace research: Ten challenges and some responses. Journal of Peace Research, 22 (2), 141-158.

Ghaith, G. M. \& Shaaban, K. A. (1994). Peace education in the ESL/EFL classroom: A framework for curriculum and instruction. TESL Reporter, 27 (2), 55-62.

Gomes de Matos, F. (1988, August). Peace and language learning. TESOL $\underline{\text { Newsletter, }} \underline{22}$ (4), 16. 
Hicks, D. (Ed.). (1988). Education for peace: Issues, principles, and practice in the classroom. London: Routledge Press.

Jacobs, G. (1990, February). ESOL and international education: Strengthening the bond. TESOL Newsletter, p. 27, 29, 33.

Jacobs, G. (1993/1994). Language use, or language usage? TESOL Matters, $\underline{3}$ (6), 15.

Jones, S. F. (1993). Culture teaching or English teaching. TESOL Matters, $\underline{3}$ (3), 19.

Larson, D. (1990, February). TESOL's role in global understanding: A possible agenda. TESOL Newsletter, 24 (1), 21.

Larson, D. (1992, February/March). Peace, justice and sustainable development: Ingredients for an emerging world order. TESOL Matters, 2 (1), 19.

Mitina, V. (1990, December). Peace education in English language teaching in the Soviet Union. TESOL Newsletter, 24 (6), 23.

Mohan, B.A. (1986). Language and content. Reading: Addison-Wesley Publishing Co.

Nunan, D. (1992). Research methods in language learning. Cambridge: Cambridge University Press.

Okamoto, M. (1993). An overview of global peace education movement. In Cremin, P. (Ed.). Education for peace. Educational Studies Association of Ireland and the Irish Peace Institute.

Oxford, R. (1993, Fall). Progress in tertiary content-based ESL instruction. TESL Canada Journal, 11 (1), 75-97.

Peterson, J. (1990, December). Human rights education and action. TESOL Newsletter, 24 (6), 27-28.

Raasch, A. (Ed.). (1993). Language teaching in a world without peace. Saarbrücken: Druckerei der Universität des Saarlandes.

Reardon, B. (1988). Comprehensive peace education: Educating for global responsibility. New York: Teachers College Press. 
Ricento, T. (1993/1994). Culture in the classroom revisited. TESOL Matters, $\underline{3}$ (6), 15.

TESOL and the United Nations: A new partnership. (1990, October). TESOL Newsletter, $\underline{24}$ (5), 31.

Turner, J. (1993). Using Likert scales in L2 research: Another researcher comments. TESOL Quarterly, 27, (4), 736-739.

Vandrick, S. (1996, December). Teaching critical thinking and reading for peace education. College ESL, $\underline{6}$ (2), 27-36.

Wenden, A. (1992, February/March). Peace education: What and why? TESOL Matters, 2 (1), $1 \& 5$. 
APPENDIX A

\section{TEACHER SURVEY}

MESSAGES SENT TO TESL-L FOR RECRUITING SUBJECTS 


\section{TEACHER SURVEY}

1) How do you define Peace Education?

2) Why have you decided to teach Peace Education in your ESL/EFL class?

3) What kinds of materials do you use?

4) What kinds of activities do you do that are related to Peace Education?

5) What kinds of topics have come up in class discussions?

6) Please describe the student population that you are working with.

7) How have students responded to your class?

8) What worked/ didn't work? 


\section{MESSAGES SENT TO TESL-L FOR RECRUITING SUBJECTS}

Date: Mon, 29 Jan 1996 13:00:23 (PST)

From: Cheryl Hill <psu01310@odin.cc.pdx.edu>

To: TESL-L@CUNYVM.BITNET

Subject: TO ALL PEACE EDUCATORS

Greetings from Portland, Oregon:

Are you teaching Peace Education in your ESL class? Would you be willing to involve your class in a case study on students' perspectives toward the teaching of peace education in an ESL class? Or, do you know someone who would be? If so please contact me at the address above.

Thank you very much in advance.

Sincerely,

Cheryl Hill

Portland State University

Date: Fri, 19 Jul 1996 12:02:51 (PST)

From: Cheryl Hill <psu01310@odin.cc.pdx.edu>

To: TESL-L@CUNYVM.CUNY.EDU

Subject: $\quad$ TO ALL PEACE EDUCATORS

Are you teaching Peace Education in your ESLEFL class? Would you be willing to participate in a Teacher Survey and possibly have your students participate in a Student Survey? If so, please contact me.

For a year now I have been working on my thesis for an MA: TESOL degree. It has been difficult getting enough subjects for my study. My goal is to have 15 teachers and 60 students complete surveys. As of now I have only 7 teachers and 12 students. I am sure that there are many more of you who teach Peace Education. This is an opportunity for you to reflect on your teaching, to get feedback from your students and to contribute to the field of TESOL a greater understanding of what Peace Education is and how it is being integrated into ESLEFL classes. 
Thank you for your time!

Cheers!

Cheryl Hill

Portland State University

Portland, Oregon, USA 
APPENDIX B

STUDENT SURVEYS

EFL VERSION I \& II

ESL VERSION

INFORMED CONSENT FORM 


\section{STUDENT SURVEY}

EFL Version I

1) Age:

2) Gender: __ Male _ _ Female

3) Country of residence:

4) How long have you studied English as a Foreign Language (EFL)?

5) Have you ever lived outside of your country for more than 3 months?

_yes _no

If yes, where?

6) Do you plan to complete a degree at a college / university?

_yes _no

If yes, what do you plan to study?

7) How did you feel about discussing Peace Issues in your EFL class at the start of the term / semester? (check those that apply)

uncomfortable _ _ interested

_comfortable _uninterested

Other feelings

Please explain.

8) How do you feel about discussing Peace Issues in your EFL class now? (check those that apply)

_uncomfortable _ _ interested

_comfortable _uninterested

Other feelings

Please explain. 
9) Do you think that you were able to improve your English skills by talking/reading/ writing about Peace Issues in your EFL class?

yes _no

Please explain.

10) Of the Peace Issues that you studied, which ones did you find interesting?

Please explain.

11) Of the Peace Issues that you studied, which ones did you find uninteresting?

Please explain.

12) Did any of the Peace Issues that you studied have an effect on you?

yes _no

Please explain. 
13) Please rate the activities that you did in your EFL class:

\section{a. Watching movies}

liked a lot

1

2

3

(usefulness for improving your English)

very useful

1

2

3

4

not useful at all

Not applicable (we did not do this in my class)

\section{b. Guest lectures}

liked a lot

1

2

3

4

5

(usefulness for improving your English)

very useful

1

2

3

4

not useful at all

Not applicable (we did not do this in my class)

\section{c. Group discussions}

liked a lot

did not like at all

1

2

3

4

5

(usefulness for improving your English)

very useful

not useful at all

$$
1
$$

2

3

4

Not applicable (we did not do this in my class) 
d. Role plays

liked a lot

1

2

3

4

(usefulness for improving your English)

very useful

1

2

3

4

not useful at all

\section{5}

Not applicable (we did not do this in my class)

\section{e. Debates}

liked a lot

1

2

3

4

did not like at all

5

(usefulness for improving your English)

very useful

not useful at all

1

2

3

4

5

Not applicable (we did not do this in my class)

\section{f. Research project}

liked a lot

did not like at all

1

2

3

4

5

(usefulness for improving your English)

very useful

not useful at all

1

2

3

4

5

Not applicable (we did not do this in my class) 
14) What materials did your teacher use?

_newspaper articles __films/videos_ _ literature

__textbook ___songs __ articles from human rights/ environmental/ development organizations

Other materials

15) Which materials were interesting?

Please explain.

16) Which materials were uninteresting?

Please explain.

17) Which materials helped you to improve your English?

Please explain. 


\section{STUDENT SURVEY \\ EFL Version II}

1) Age:

2) Gender: __ Male __Female

3) Country of residence:

4) How long have you studied English as a Foreign Language (EFL)?

5) Have you ever lived outside of your country for more than 3 months?

_yes _no

If yes, where?

6) Do you plan to complete a degree at a college / university?

yes _no

If yes, what do you plan to study?

7) How did you feel about discussing Peace Issues in your EFL class at the start of the term / semester?

—very comfortable _comfortable _ somewhat comfortable _not comfortable _very uncomfortable Please explain.

8) What was your level of interest in Peace Issues at the start of the term / semester?

_ very interested __interested __ somewhat interested _ _ not interested _ very uninterested

Please explain. 
9) How do you feel about discussing Peace Issues in your EFL class now?

__ very uncomfortable __ not comfortable __somewhat comfortable _ _ comfortable _ _ very comfortable Please explain.

10) What is your level of interest in Peace Issues now?

_

Please explain.

11) Were you able to improve your English by studying Peace Issues in your EFL class?

\section{LISTENING COMPREHENSION}

__ improved a lot __ improved __ improved somewhat _ improved very little __didn't improve SPEAKING

_ didn't improve _ _improved very little __improved somewhat _ improved _ improved a lot

\section{READING}

_ improved a lot _ improved __improved somewhat _ improved very little __didn't improve

\section{WRITING}

_ didn't improve _ improved very little _ improved somewhat _ improved _ improved a lot

Please explain. 
12) Please rank the Peace Issues that you studied from 1---most interesting to 5---least interesting (write "NA" if you did not study this Peace Issue):

Development (poverty, hunger)

Environment

Human Rights

__Peace

Other

Please explain.

13) Please check $(\checkmark)$ the Peace Issues that had an effect on you.

Development (poverty, hunger)

Environment

Human Rights

Peace

Other

Please explain. 
14) Please rank the activities that you did in your EFL class from 1---liked least to 7---liked most (write "NA" if you did not do this activity in your class):

_Debates

_Group discussions

_Group* lectures

_Research projects

_Role plays

_Watching movies

Other

Please explain.

*This should have read "Guest". Because of this mistake, this item was not used in the analysis.

15) Please rank the activities that you did in your EFL class from 1---most useful (for improving my English) to 7---least useful (write "NA" if you did not do this activity in your class):

_Debates

_Group discussions

_Group* lectures

Research projects

_Role plays

_Watching movies

Other

Please explain.

*This should have read "Guest". Because of this mistake, this item was not used in the analysis. 
16) Please rank the materials that were used in your EFL class from 1---least interesting to 7--most interesting (write "NA" next to materials that were not used):

Articles from human rights, environmental, development organizations

Films, videos

Literature

Newspaper articles

__ongs

Textbook

Other

Please explain.

17) Please rank the materials that were used in your EFL class from 1---most useful (for improving my English) to 7---least useful (write "NA" next to materials that were not used):

_._Articles from human rights, environmental, development organizations

_Films, videos

Literature

Newspaper articles

Songs

Textbook

Other

Please explain. 


\section{STUDENT SURVEY}

ESL Version

1) Age:

2) Gender: __ Male __ Female

3) Country of residence:

4) How long have you lived in the U.S.?

5) How long have you studied English as a Second Language (ESL) in the U.S.?

6) Have you lived in any other countries, besides the U.S. and your own country, for more than 3 months?

_yes _no

If yes, where?

7) Did you study at a college or university in your home country?

yes _no

If yes, what was your major?

8) Are you planning to complete a degree in the U.S.?

yes _no

If yes, what do you plan to study?

9) How did you feel about discussing Peace Issues in your ESL class at the start of the term / semester?

_very comfortable comfortable somewhat comfortable not comfortable very uncomfortable

Please explain. 
10) What was your level of interest in Peace Issues at the start of the term / semester?

_ very interested __interested __somewhat interested _ _ not interested _

Please explain.

11) How do you feel about discussing Peace Issues in your ESL class now?

_very uncomfortable _ _ not comfortable _ somewhat comfortable __ comfortable _ _ very comfortable Please explain.

12) What is your level of interest in Peace Issues now?

_

Please explain.

13) Were you able to improve your English by studying Peace Issues in your ESL class?

\section{Listening comprehension}

__improved a lot __ improved __ improved somewhat _ improved very little _ didn't improve

Speaking

_ didn't improve __improved very little _ improved somewhat _ improved _ improved a lot

\section{Reading}

_ improved a lot _ improved _ improved somewhat _ _improved very little _ didn't improve Writing

__didn't improve __improved very little _ improved somewhat __improved _ improved a lot 
14) Please rank the Peace Issues that you studied from 1---most interesting to 5---least interesting _ Development (poverty, hunger)

Environment

_Human Rights

_Peace

Other

Please explain.

15) Please check $(\checkmark)$ the Peace Issues that had an effect on you.

Development (poverty, hunger)

Environment

Human Rights

Peace

_Other

Please explain.

16) Please rank the activities that you did in your ESL class from 1---liked least to 6---liked most:

Debates

_ Group discussions

_ Guest lectures

Research projects

Role plays

Watching movies 
17) Please rank the activities that you did in your ESL class from 1---most useful (for improving my English) to 6---least useful:

_Debates

_Group discussions

Guest lectures

_Research projects

Role plays

Watching movies

18) Please rank the materials that were used in your ESL class from 1---least interesting to 7--most interesting:

Articles from human rights, environmental, development organizations

Films, videos

Literature

Newspaper articles

__ Songs

_Textbook

Other

Please explain 
19) Please rank the materials that were used in your ESL class from 1---most useful (for improving my English) to 7---least useful:

Articles from human rights, environmental, development organizations

_Films, videos

_Literature

Newspaper articles

__Songs

_Textbook

Other

Please explain. 


\section{INFORMED CONSENT FORM}

(prospective subjects for the survey)

\section{Dear ESL/EFL Student,}

I am a graduate student at Portland State University in Portland, Oregon, USA. The attached questionnaire that you have been given by your teacher is part of a study I am doing. I am asking ESL/EFL students to answer questions on their attitudes towards the teaching of peace education in ESL/EFL classes. The purpose of this study is to help teachers to decide whether or not to teach peace education in ESL/EFL classes. And, if so, how it could best be taught. Although you may not receive any direct benefit from this study, your input will greatly help ESL/EFL teachers in the future.

Participation in this study is completely voluntary (your choice). If you do not wish to fill out the questionnaire, it will NOT have any effect on your grade for this course or your relationship with the researcher, the teacher or the institution.

If you decide to participate, all of the information that you give me will be kept confidential (secret).

If you would like to take part in this study, please fill out the attached questionnaire and return it to your teacher.

Thank you,

\section{Cheryl Hill}

If you have any concerns or questions about this study, please contact the researcher, Cheryl Hill, at the following e-mail address: psu01310@odin.cc.pdx.edu, or you may call: (503) 223-7927. You may also contact the Chair of the Human Subjects Research and Review Committee, Research and Sponsored Projects, 105 Neuberger Hall, Portland State University, (503) 725-3417. 
APPENDIX C

RECOMMENDED

STUDENT SURVEY 
The Recommended Student Survey can be used in ESL and EFL settings. It contains five demographic questions, four 5-point Likert scales measuring comfort with and interest in peace issues at the beginning and end of the semester, and one 5point Likert scale measuring subjects' attitudes toward the improvement of their English. The last five items elicit subjects' rankings of the peace issues, activities, and materials used in their class.

In the first section of the Recommended Student Survey, demographic question 3, "What is your home country", was changed from its original wording: "Country of residence". The purpose for this item on the original versions of the Student Survey was to address the question of whether or not one's country of residence has an influence on an interest in and/ or comfort with peace issues. Data collected in the EFL class in Israel pointed to the need for a revision of this item. The teacher of this class indicated on the Teacher Survey that a small population of students in her class had immigrated from the former Soviet Union. All of the EFL students in Israel indicated that their country of residence was Israel. It is possible that some of the subjects in that class had spent a majority of their lifetime in the former Soviet Union and are, therefore, more influenced by that culture than Israeli culture.

Items which ask subjects to comment of whether or not they plan to complete a university degree and what they plan to study do not appear on the Recommended Student Survey. The researcher predicted that data collected from these items could be used in this study to investigate whether or not a connection existed between a 
subjects' field of study and one's interest in peace education. In two of the participating classes, the EFL classes in Italy and Japan, all of the subjects were working towards a degree in the same field. In the other two classes, the EFL class in Israel and the ESL class, subjects' academic interests varied; therefore, this variable could not be considered when investigating patterns among the four classes with regard to possible reasons for a subject's interest or disinterest in peace education. According to Brinton, Snow and Wesche (1989), content-based courses of the themebased model such as the classes in Israel and the U.S. are common. A feature of these classes is that students do not share a common purpose for studying English, as with the ESP classes. Thus, this feature could not be used to investigate a connection between interest in and comfort with peace issues and intended field of study.

The following demographic questions specific to the ESL setting do not appear on the Recommended Student Survey: "How long have you lived in the U.S."; and "Are you planning on completing a degree in the U.S.".

On the Recommended Student Survey 5-point Likert scales are used for the four survey items which measure interest in and comfort with peace issues at the beginning and end of the semester. Two changes were made to the Likert scales. On the Recommended Student Survey the positive values are on the left side of all Likert scales throughout the survey and the negative values are found on the right side (rather than alternating the values).

Item 11 on the Recommended Student Survey asks subjects to rank the peace 
issues that they studied. On the EFL I, EFL II, and ESL Surveys, "peace issues" were divided into four categories: development, environment, human rights, and peace. The fourth category, peace, was not included on the Recommended Student Survey. At the beginning of this study, the researcher defined peace education as being synonymous with global education which is divided into the four branches listed above.

Items 12-15 are rankings measuring subjects' assessment of the activities and materials used in their ESL/EFL class. For the Recommended Survey the values on the rankings are consistent. On all rankings one corresponds to the most positive response. 


\section{RECOMMENDED \\ STUDENT SURVEY}

1) Age:

2) Gender: _Male _ Female

3) What is your home country?

4) Have you ever lived outside of your home country for more than 3 months?

—yes no

If yes, where?

5) How long have you studied English? 
6) How did you feel about studying peace issues in your English class at the beginning of the semester?

very comfortable not comfortable at all
1
2
3
4
5

Please explain.

7) What was your level of interest in peace issues at the beginning of the semester? very interested not interested at all
1
2
3
4
5

Please explain.

8) How do you feel about studying peace issues in your English class now?

very comfortable

$$
1
$$

2

3 not comfortable at all

5

Please explain.

9) What is your level of interest in peace issues now?

very interested

not interested at all
1
2
3
4
5

Please explain. 
10) Were you able to improve your language skills by studying peace issues in your English class?

\section{LISTENING COMPREHENSION}

improved a lot

didn't improve at all

1

2

3

4

5

SPEAKING

improved a lot

didn't improve at all

1

2

3

4

5

READING

improved a lot

didn't improve at all

1

2

3

4

5

WRITING

improved a lot

didn't improve at all

1

2

3

4

5

Please explain.

11) Please rank the peace issues that you studied from 1---most interesting to 4---least interesting (write "NA" if you did not study this issue):

_ Development Issues

Environmental Issues

_Human Rights Issues

Other

Please explain. 
12) Please rank the activities that you did in your English class from 1---liked most to 7---liked least (write "NA" if you did not do this activity in your class):

_Debates

_Group discussions

_ Guest lectures

_Research projects

Role plays

_Watching movies

_ Other

Please explain.

13) Please rank the activities that you did in your English class from 1---most useful (for improving my English) to 7---least useful (write "NA" if you did not do this activity in your class):

Debates

_ Group discussions

_Group lectures

_Research projects

_Role plays

_Watching movies

Other

Please explain 
14) Please rank the materials that were used in your English class from 1---most interesting to 7---least interesting (write "NA" next to materials that were not used):

Articles from human rights, environmental, development organizations

_Films, videos

Literature

Newspaper articles

L_ongs

_Textbook

Other

Please explain.

15) Please rank the materials that were used in your English class from 1---most useful (for improving my English) to 7---least useful (write "NA" next to materials that were not used):

_Articles from human rights, environmental, development organizations

_Films, videos

_Literature

_Newspaper articles

_Longs

Textbook

Other

Please explain. 
APPENDIX D

CARD SORT 
Results from the Card Sort have been moved to the appendices as they do not relate to the research questions of this study. The purpose for carrying out the Card Sort was to find out what Student Survey respondents' semantic categories were for peace education terms when they filled out the questionnaire. The only class that took part in the Card Sort was the ESL class which had a global education focus with peace issues as a sub-topic. Subjects for the Card Sort were recruited from the ESL class in Oregon because it was geographically closest to the researcher.

To create the materials for the Card Sort, the researcher asked the teacher of the participating ESL class for a list of peace issue terms that her students had learned. From that list, the researcher selected the terms which seemed to be among the most commonly found terms in the literature on peace education. It was essential to limit the number of terms in order that the task could be completed by the students in about 20 minutes. The researcher then made a set of 27 cards, one term per card, for each of the subjects.

Each student received a set of 27 cards and a sheet of paper on which the following categories were written: Development Issues, Environmental Issues, Human Rights Issues, and Peace Issues. The students were given 20 minutes to sort the 27 cards into the four categories. The researcher explained to the students that a card could be used more than once or not at all.

Listed below are the 27 terms used in the Card Sort. One term appeared on each card. The numbers were omitted on the cards so as not to influence the way in 
which the participants sorted the cards.

1 sustainable society

2 ignorance

3 population growth

4 fear

5 malnutrition

6 illiteracy

7 oppression

8 materialism

9 cooperation

10 apathy

11 greed

12 global warming

13 sensitivity

14 industrialization

15 respect

16 injustice

17 corruption

18 arms race

19 love

20 education

21 immigration

22 economic development

23 tropical rain forests

24 re-forestation

25 equitable distribution

26 non-violent resistance

27 world food production 

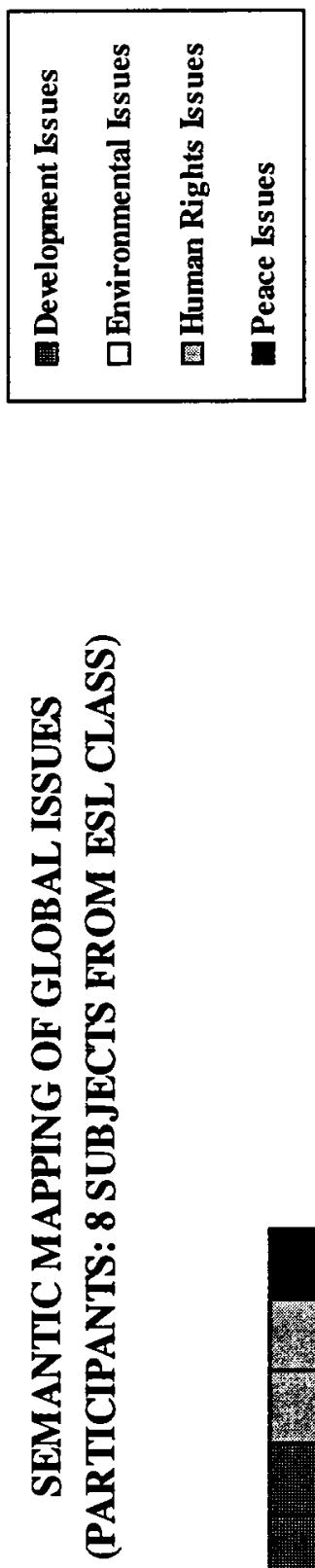
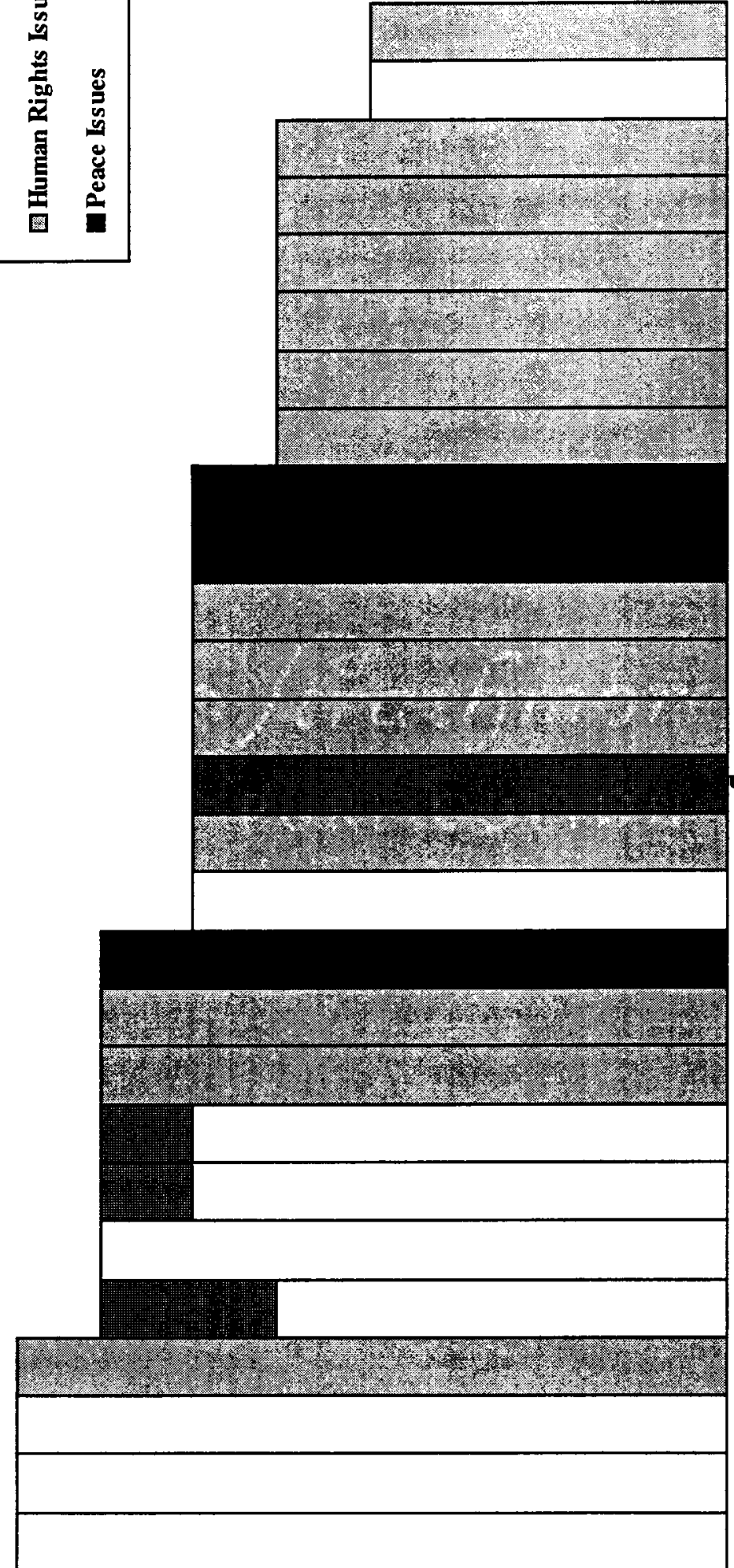

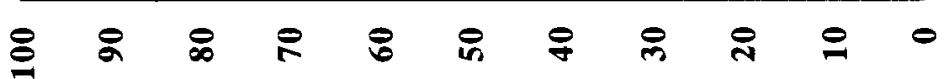

TOEI SUU.

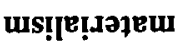

Кวอมวุ!I!!

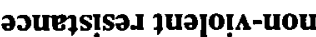

рәว.18

Sypede

JEวJ

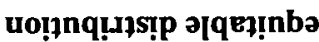

DAOI

poodsəג

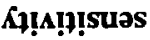

uoṇdnd.soJ

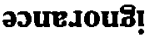

uonjonposd pooj PIJOM

uo!̣esnpa

41MOد8ิ uọpe|ndod

uo!̣exadoos

uop̣e.Jo!̣um!

uoṭssajddo

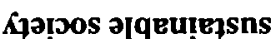

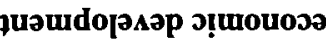

uọ̣ez!|[!!.jsnpu!

uo!̣!.Jpnujew

อง!̣sn!̣!

uọ̣eqsadoj-ad

S7sajoj u!̣ed [Eว!dos?

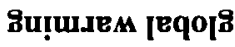

